
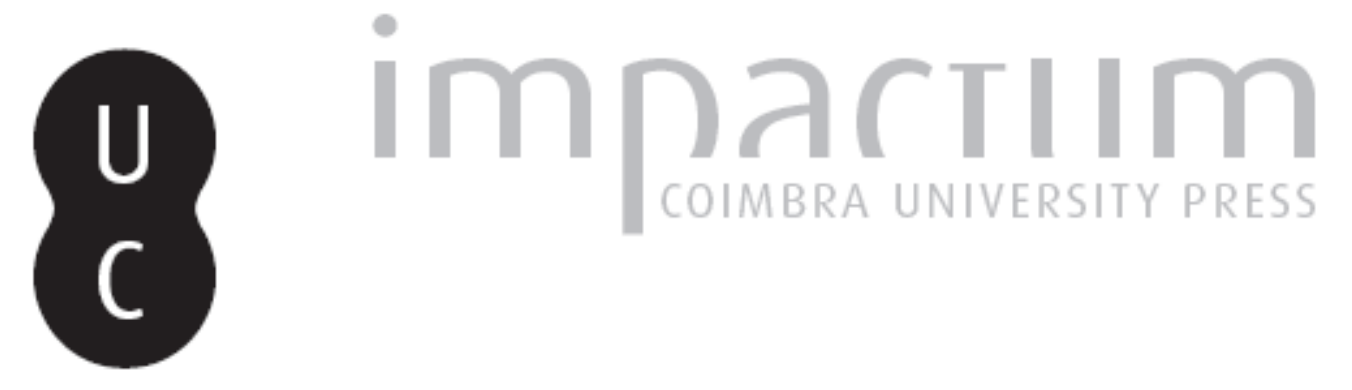

\title{
Mitologia e Drama na Metafísica de Plotino
}

\section{Autor(es): $\quad$ Santos, David G.}

Publicado por: Centro de História da Universidade de Lisboa

URL persistente:

URI:http://hdl.handle.net/10316.2/23840

DOI:

DOI:http://dx.doi.org/10.14195/0871-9527_18_8

Accessed : $\quad$ 26-Apr-2023 15:35:53

A navegação consulta e descarregamento dos títulos inseridos nas Bibliotecas Digitais UC Digitalis, UC Pombalina e UC Impactum, pressupõem a aceitação plena e sem reservas dos Termos e Condições de Uso destas Bibliotecas Digitais, disponíveis em https://digitalis.uc.pt/pt-pt/termos.

Conforme exposto nos referidos Termos e Condições de Uso, o descarregamento de títulos de acesso restrito requer uma licença válida de autorização devendo o utilizador aceder ao(s) documento(s) a partir de um endereço de IP da instituição detentora da supramencionada licença.

Ao utilizador é apenas permitido o descarregamento para uso pessoal, pelo que o emprego do(s) título(s) descarregado(s) para outro fim, designadamente comercial, carece de autorização do respetivo autor ou editor da obra.

Na medida em que todas as obras da UC Digitalis se encontram protegidas pelo Código do Direito de Autor e Direitos Conexos e demais legislação aplicável, toda a cópia, parcial ou total, deste documento, nos casos em que é legalmente admitida, deverá conter ou fazer-se acompanhar por este aviso.

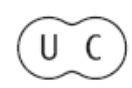



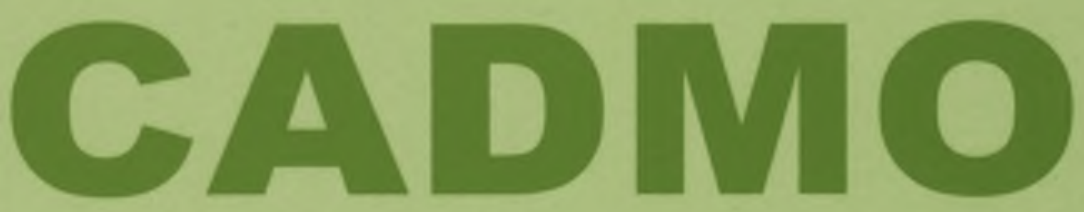

Revista de História Antiga

\author{
Centro de História \\ da Universidade de Lisboa
}

18

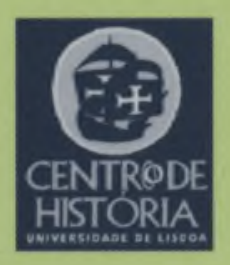

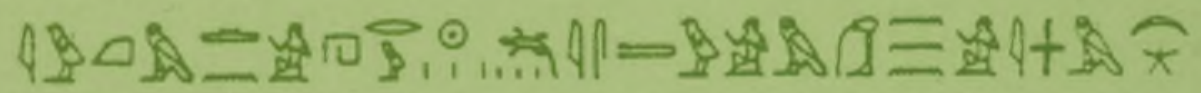

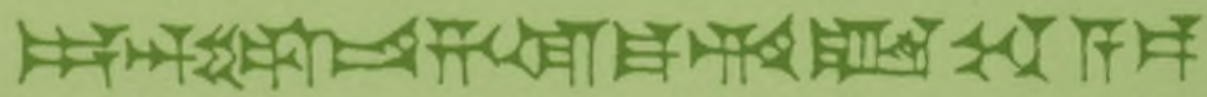

MHNIN AEI $\Delta$ E $\Theta E A ~ \Pi H \Lambda H I A \triangle E \Omega$ 


\title{
MITOLOGIA E DRAMA NA METAFÍSICA DE PLOTINO
}

\author{
DAVID G. SANTOS \\ Universidade de Lisboa \\ david.g.santos@gmail.com
}

\section{Resumo}

Uma aproximação à complexidade do fenómeno religioso no âmbito profundo do que serve de grande móbil para a construção metafísica de Plotino não se pode limitar a uma mera abordagem sociológica, psicológica, antropológica, fenomenológica ou até historicista. A complexidade desta produção mitológica surpreende pelo seu grau de universalidade e requer uma análise antes de tudo o mais multidisciplinada e crítica. Apesar de múltiplas evidências de um real paralelismo entre variadas narrativas mitológicas universais e da respectiva proeminência cultural do material mitológico para o despertar da consciência reflexiva, o que mais surpreende é justamente interceptar um substracto arcaico na metafísica de Plotino. Este trabalho pretende reconhecer que apesar da superficialmente límpida construção metafísica de Plotino (que para a maioria dos especialistas só peca por irracionalidade no fechamento místico do seu sistema) tem na sua origem, talvez, os mesmos agentes que os paradigmas da mitogenia universal.

Palavras-chave: Plotino; Mitologia; Religião, Metafísica; Paradigmas; Mitogenia; Filosofia; Drama; Pensamento arcaico; Substrato religioso da metafísica.

\section{Résumé}

Une approche à la complexité du phénomène religieux dans l'immense domaine qui sert de grand mobile à la construction métaphysique de Plotin ne peut aucunement se circonscrire tout simplement à une étude sociologique, psychologique, anthropologique, phénoménologique ou même historiciste. La 
complexité de cette production mythologique est surprenante, surtout à cause de son universalité et exige une analyse plutôt multidisciplinée et critique. Malgré les multiples évidences d'un parallélisme réel entre les nombreux récits mythologiques universels et la respective proéminence culturelle du matériel mythologique pour l'éveil de la conscience réflexive, ce qui est particulièrement singulier c'est justement intercepter un substrat archaïque dans la métaphysique de Plotin. Cet ouvrage prétend reconnaître que malgré la limpide construction métaphysique de Plotin (qui ne l'est que superficiellement, et que pour la plupart des spécialistes ne pèche que par irrationalité dans la clôture mystique de son système), elle possède vraisemblablement à son origine les mêmes agents que les paradigmes de la mythogénie universelle.

Mots-clés: Plotin; Mythologie; Religion; Métaphysique; Paradigmes; Mythogénie; Philosophie; Drame; Pensée archaïque; Substrat religieux de la métaphysique.

\section{Introdução e enquadramento teórico}

De um ponto de vista meramente estrutural, o presente trabalho divide-se em dois grandes blocos: no primeiro procuraremos fazer uma análise e comentário crítico de um só tratado de Plotino; partindo do primeiro parágrafo daquele que se supõe ser o último tratado escrito pelo filósofo egípcio antes da sua morte, о ПЕPI TOY ПРОТО AГA $\Theta O N$ KAI T $\Omega N$ A $\Lambda \Lambda \Omega N$ A $\triangle A \Theta \Omega N$, da Enéada I, 7; tentaremos logo de seguida, no segundo grande bloco deste trabalho, estabelecer as relações estruturais que melhor ali se vislumbrarem, reconduzindo-as não só a outras passagens do corpus plotiniano, mas principalmente a uma perspectiva total da obra de Plotino e dos seus matizes, como argumentaremos, profundamente mítico-simbólicos. Em jeito de conclusão, a presente reflexão terminará com uma meditação de carácter mais desprendido da letra do texto do filósofo egípcio, procurando reintegrá-lo, em traços macroscópicos, na experiência filosófico-metafísica de Plotino do universo e economia da consciência religiosa mitológica grega e universal.

\section{O eixo metafísico essencial de Plotino: o Uno, o Bem, a Alma e o Intelecto}

O tratado I, 7 de Plotino é um dos mais breves de toda a sua literatura; apesar da opinião de Porfírio, seu discípulo, segundo o qual 
na data em que foi escrito, as capacidades do mestre já se encontrariam de certa forma em ruptura, nele se concentram e recapitulam subtilmente algumas das suas mais significantes posições religiosas e morais. Tal como A. H. Armstrong o menciona na sua brevíssima introdução ao referido tratado é um facto que nele encontramos "o essencial do seu ensinamento moral e religioso"(1). Contudo, cremos, muito mais se oculta na letra do texto do filósofo egípcio. Plotino provavelmente reconhecendo que a sua morte estaria perto, estabeleceu de forma quase lapidar o seguinte texto:

\section{a) Comentário Crítico, I. 7. 1, 1-8}

Desde as primeiras linhas do presente tratado, observam-se de imediato algumas das questões mais basilares de toda a obra de Plotino: unitaristas ou intérpretes diacronistas da sua obra, ninguém pode ignorar o lugar fundamental que o já muito glosado tò d́ $\gamma \alpha \theta o ́ v$ ocupa no pensamento do filósofo egípcio. O título dado por Porfírio ao tratado é, aliás, bem testemunha do que referimos; contudo o que é sem dúvida estranho é que na verdade o "Bem" é um vocábulo muito poucas vezes utilizado por Plotino em comparação com a terminologia $\tau \grave{o}$ "Ev . Todavia e numa melhor apreciação ainda há uma outra questão que merece desde logo ser relevada: o substantivo "Uno" é muitas vezes

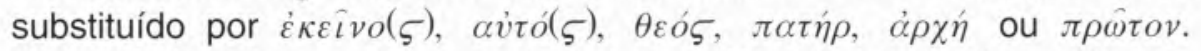
$\mathrm{Na}$ verdade o termo "Uno" que se tornou tão célebre ao longo da história é utilizado, diríamos, quase de forma fortuita e parece que inserido num mero hábito semântico. Em muitos lugares das Enéadas é o termo "Bem» que emerge; no tratado VI. 9, um dos passos mais fundamentais do corpus plotiniano, onde se descreve a ascensão e o famoso regresso ( $\dot{\varepsilon} \pi \sigma \tau \rho \circ \varphi \dot{)})$ dos seres, não só raramente se lê no texto "Uno", como a partir do capítulo 6 tal designação chega mesmo a ser abolida. Antes de Plotino descrever o processo derradeiro de união mística, o último nome para a entidade suprema é "o Bem". De cada vez que Plotino trata a questão da união da alma com esta entidade, os nomes que prefere são sempre "o Bem», "Deus", "Ele" ou até "Origem" quando estamos perante a problemática do contacto metafísico entre esta entidade e os seres que Ihe são inferiores nesta hierarquia metafísica. Obviamente que quando Plotino se abeira de diferentes matérias ou quando sobre os mesmos assuntos toma perspectivas diferentes, tem em conta aspectos diversos desta Entidade Suprema 
e por isso designa-a de formas variadas. Não é quase novidade na medida em que de certa forma faz parte até da herança religiosa contemporânea intelectualmente cuidada: a Entidade Suprema transcende os seus nomes próprios, ou melhor, a este Uno, a este Deus, a este Bem não se the coaduna nenhum nome que the seja próprio. Plotino refere isto mesmo que dizemos quando falamos desta entidade suprema: v́r $\dot{\varepsilon} \rho \tau \alpha \tau o v$ - como esta entidade está acima de todo o nome, devemos até ter cuidado quando nos referimos a ela como "entidade suprema»: para denotar o mais alto princípio da metafísica plotiniana, devemos sem dúvida esvaziar a palavra "entidade» da sua conexão ao termo latino ens.

Não existe sequer também um princípio passível de ser reconduzido a toda uma lógica de cariz cronológico relativo ao uso semântico dos termos que designam esta Entidade: de acordo com os seus diferentes aspectos, esta Entidade Suprema é aparentemente nomeada sem uma regra rígida. Plotino nem sempre usa um ou outro termo de forma homogénea, porém as suas escolhas não parecem ser completamente arbitrárias, uma vez que não só não parecem ser influenciadas pelo contexto que as precede, como por outro lado, pelo menos as duas principais nomenclaturas, a de "Uno" e a de "Bem» surgem num pé de igualdade. É interessante que Plotino aplica o mesmo tratamento e os métodos de pensamento metafísico às duas nomenclaturas: no tratado $\mathrm{VI}, 7$, tal como tinha feito no $\mathrm{VI}, 9$ relativamente ao Uno, liberta o Bem do movimento, do pensamento, e de resto de qualquer outra qualidade ou atributo que pudesse de alguma forma forçá-lo a uma limitação ontológica da entidade que possibilita a própria possibilidade de haver outras entidades colocadas, evidentemente, numa posição metafisicamente inferior, como de resto se tornou lei nas metafísicas neoplatonistas posteriores. Existem necessidades de contexto que exigem por vezes a permuta do nome «Bem» em favor do termo «Uno", como por exemplo em V, 6, mas regra geral toda a terminologia que gravita em torno desta entidade é tratada de forma metodologicamente semelhante. De resto, seguindo aliás o mesmo método, até mesmo a palavra "Bem» chega a ser rejeitada da mesma forma que "Uno": ambos os termos em última análise caem no mesmo erro ao qual deveriam escapar: o de proporem algo de positivo sobre essa entidade conferindo-lhe um sentido que desde logo à partida lhe limita a natureza super-abundante e produtiva de realidade.

De repente Plotino coloca-nos no centro coronário de toda a sua construção filosófica: logo na primeira oração vemos como o filósofo 
egípcio recorre a noções que lhe são certamente axiais - Bem, vida e unidade são conceitos que logo neste primeiro passo concorrem para a eficácia do que aqui está em questão. Poderia o Bem de uma coisa ser outra coisa senão a actividade natural da vida que lhe é inerente? Acaso poderia ser o Bem de alguma coisa ser outra coisa senão a actividade própria que lhe é mais natural? Se uma coisa for feita de partes, poderia o seu Bem ser outra coisa senão o funcionamento da melhor parte e do que então lhe é natural e próprio? Plotino não está aqui a debater directamente a questão do Uno, mas está sem dúvida a ter em conta uma questão que lhe é inerente: a unidade. O Bem de uma coisa é a actividade plena que lhe é natural: ontologicamente falando vemos desde logo como se acomoda o esquema plotiniano dos seres: todos os seres, desde o mais alto e primário dos seres até ao que está colocado mais inferiormente são não só unos numa unidade funcional e natural que lhes é própria, como de um certo ponto de vista pertencem à grande unidade, ao grande Uno que se perfaz na totalidade dos seres e das suas actividades. Em Plotino há pelo menos três grandes grupos metafísicos da unidade:

1. A unidade das entidades que embora isoladas umas das outras estão concatenadas numa qualquer ordem; estamos aqui, por exemplo, perante o caso de um exército ou de um coro que

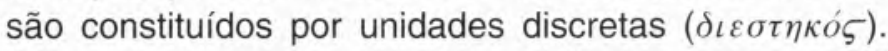

2. Coisas como casas e navios são as outras entidades que apresentam um outro grau de unidade. Plotino apelida-os de

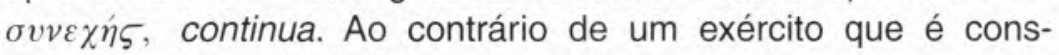
truído de elementos discretos, estes estão conectados regra geral numa determinada forma que não só os configura física e funcionalmente como faz com que por isso transcendam a mera soma das suas partes discretas e sejam de certa forma uma entidade contínua.

3. O terceiro tipo de unidade para Plotino são os seres que apresentam tal como são numa unidade orgânica vital. Plantas e animais são denotados pelo filósofo egípcio pela fórmula $\tilde{\varepsilon} v$ $o ́ v \tau \alpha$, enquanto os seres do ponto 2. são regra geral tratados

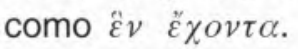

Plotino não está aqui a inovar de forma absoluta: Platão no seu diálogo Parménides (165 E ff.) mostra as consequências da não existência do Uno no que diz respeito às outras coisas $(\tau \alpha \tilde{\alpha} \lambda \lambda \alpha)$. A diferença, 
contudo, é que se no Parménides, Platão examina as consequências na existência em geral das outras coisas retirando conclusões gerais, de carácter especulativo e metafísico, Plotino acerca-se sempre das consequências práticas da perda da unidade para as partes que perfazem tal ou tal ser. Um ser que perca a sua unidade está condenado ao seu desfasamento em partes e componentes. O método de Plotino é usado amiúde ao longo dos seus textos - no tratado $\mathrm{VI}, 9$, temos também uma pergunta em tudo semelhante à que atrás referimos: $\tau i$

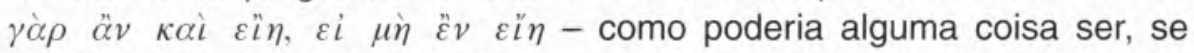
não fosse una? Se privarmos ( $\dot{\alpha} \phi \alpha \iota \rho \varepsilon \hat{\imath} v)$ uma entidade do seu tipo de unidade, isto é, do tipo de unidade acerca do que é dito dos ôv $v \alpha$ ( $\tau o \hat{v} \ddot{\varepsilon} v$ ö $\lambda \dot{\varepsilon} \gamma \alpha \tau \alpha \iota$ ), ela perde o seu ser. O método de análise das três categorias de unidade é o mesmo em vários pontos da obra de Plotino: aplicado a 1., 2. ou 3., isto é, cessando a unidade que constitui os seres das categorias citadas, deixam também de existir as entidades em causa no seu todo. Retirada a unidade que constitui os entes, desfeito o poder unitivo desta forma, os seres em causa deixam automaticamente de existir (Eivol).

Poderemos então dizer que o Bem para uma coisa poderá ser outra diferente do que a actividade natural da sua vida? A resposta é evidentemente que não. Mas um dos conceitos-chave que entra desde logo também em jogo é a noção de "vida». Em VI, 9 e VI, 39, Plotino debruçando-se também sobre a conceptualização em torno da unidade e da multiplicidade, avança a tese segundo a qual uma das evidências de que o ser é múltiplo é simplesmente o facto de possuir $(\varepsilon \dot{\varepsilon} \varepsilon \iota v)$ vida $(\xi \omega \eta \dot{v} v)$ e intelecto $(v o \hat{v} v)$. A vida está combinada com o ser numa importante passagem de um diálogo de Platão: no Sofista (249 A) encontramos pelo menos duas passagens com expressões em tudo semelhantes. Para perceber a passagem de Plotino é preciso portanto ter em conta o argumento adicional de que o ser não é

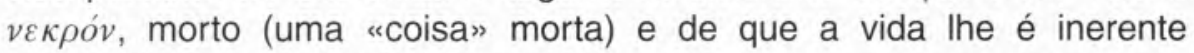
constitutivamente. A tríade ser, vida e intelecto parecem ser elementos inseparáveis de uma pluralidade que se auto-implica quando se fala, a título de exemplo, de um ser do tipo 3: um homem, entre outras coisas, é antes de mais um ser que é vivo e que tem em si um intelecto cuja actividade natural é pensar, ascendendo nas diversas escaladas do inteligível. Se uma coisa é feita de muitas partes, à semeIhança aliás do homem, o bem absoluto é a actividade natural da melhor parte desse conjunto de coisas que organizadas o constituem numa organicidade que lhe confere em simultâneo uma identidade 
própria. No que diz respeito à emergência da ideia de «natural», de "natureza", tal é a riqueza desta primeira passagem do tratado em questão, que também aqui se joga uma noção não menos fundamen-

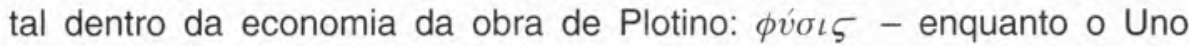
não possui uma natureza que se Ihe possa atribuir uma vez que em rigor se trata de uma entidade vazia de atributos ou quaisquer qualificações, no trâmite do texto sobre o qual nos debruçamos, a questão, como de resto já notámos, instala-se noutro patamar da metafísica

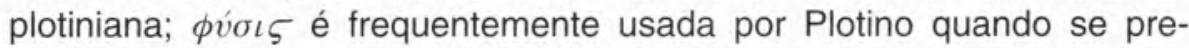
tende referir à essência de uma qualquer entidade. "Y $\Lambda \mathrm{H}, \quad \sigma \hat{\omega} \mu \alpha$,

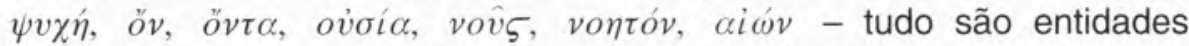
sobre as quais repetidamente encontramos referências conjuntas com a ideia de uma natureza que as define e esta passagem, em I, 7, 1., In 2, não é uma excepção, uma vez que surge nas imediações do aparecimento da temática da alma e da sua actividade. A actividade da alma é o seu bem natural - tal como de resto se processa de igual modo com outras entidades. Todos os entes têm o seu funcionamento natural que Ihes é próprio e que os dirige de uma maneira ou de outra para o melhor; com a alma não poderia ser diferente, com a agravante de que Plotino nos diz que se uma alma for da melhor qualidade ontológica, a sua actividade não vai só estar virada para o que the é por natureza melhor, mas vai certamente estar dirigida para o bem absoluto. Por um lado Alma e Uno são sem dúvida entidades diferentes, contudo é através da alma que se comunica a unidade aos

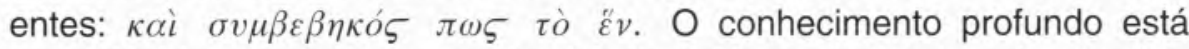
sem dúvida colocado na vov́ $(\mathrm{V}, 9,4-8)$, o conhecimento de tipo secundário tem o seu devido lugar na $\psi v \chi \tilde{\eta} \zeta$. O conhecimento sobre os dados sensíveis deve preferencialmente chamar-se $\delta \delta ́ \xi \alpha$. Apesar da tripartição desta epistemologia, a metafísica de Plotino insiste sempre na ideia de que nenhuma parte do todo do conhecimento pode ser isolada do seu conjunto: qualquer parte deste universo da $\dot{\varepsilon} \pi \iota \sigma \tau \dot{\eta} \mu \eta$, caso seja colocado diante de nós ( $\pi \rho \circ \chi \varepsilon\llcorner\rho \iota \sigma \theta \varepsilon \dot{v} v$, vide IV, $9,5,13)$ e devidamente isolado ( $\pi \rho \varepsilon_{\varepsilon} \dot{\tau} \alpha \kappa \tau \alpha \iota$, IV, 9, 5, 14), mesmo que o ignoremos, traz consigo todas as outras partes do saber (IV, 9, 5, 15). Todas as partes têm em si a potência do todo por uma razão aparentemente simples: se por um lado todas as fracções mantém entre si uma teia de relações de dependência com os níveis que Ihes sejam anteriores e superiores do ponto de vista ontológico, por outro lado e em último reduto a entidade metafísica última surge como a origem de tudo $(\dot{\eta} \pi \dot{\alpha} v \tau \omega \nu \dot{\alpha} \rho \chi \dot{\eta})$. O Uno é o tudo que não se pode, como de 
resto já vimos, sequer reduzir a uma hipotética condição de unidade

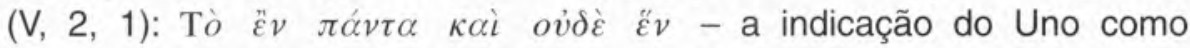
origem extra temporal de tudo, e o facto de que enquanto suposta entidade a sua natureza íntima se prende justamente com um vazio de determinação intrínseca que lhe é inerente, funciona como a base de toda uma sistemática explicação acerca da metafísica do mundo. Há em Plotino o reconhecimento explícito de que isso que muitas vezes se designa como "Uno não é nada para si mesmo" e que em absoluta verdade "nenhum nome lhe convém" sendo-o apenas "para os outros" única e exclusivamente em função da sua necessidade de nomeação. Escapando a todas as determinações do ser, do devir e do pensar, o que é engendrado é sempre "menor do que ele» $(\mathrm{V}, 1,6)$ e sendo esta entidade o princípio e potência de todas as coisas, sendo todo o ser o seu efeito, apesar disso e conforme o que referimos, ele mantém-se além de tudo, além da essência, numa transcendência que o preserva de toda a limitação ontonoética e ontológica. Tudo no universo plotiniano colhe do poder do Uno e da sua auto-emanação genesíaca e poiética, deste não ser nada e em simultâneo do seu poder [de] ser tudo (cf. V, 4, 2.) do qual tudo numa imanência infinita procede e para o qual tudo se converte.

\section{b) Comentário Crítico, I. 7. 1, 9-21}

A coluna vertebral da metafísica plotiniana está basilarmente bem expressa na presente passagem: se alguma coisa não dirigir a sua actividade para outra coisa, uma vez que é o melhor dos seres e a todos os transcende, então essa entidade só pode ser o Bem. Nada está em rigor separado, todas as coisas permanecem no seu princípio quanto dele procedem e a ele se convertem: considerando que o Uno engendra eternamente, Plotino é sempre explícito ao dizer que o engendrado é «menor do que ele» $(V, 1,6)$. Sendo esta entidade o princípio e a potência de todas as coisas, sendo todo o ser o seu efeito, o Uno mantém-se além de tudo, além da essência na transcendência da sua primeira hipóstase, enquanto o Intelecto se torna a visão que de si tem quando este princípio para si mesmo se volta $(V, 1,7)$. $O$ Bem transcende o Intelecto justamente na igual medida em que pelo menos de um certo ponto de vista, este ser lhe é exterior e por isso inferior. O Intelecto, o conhecer é em si mesmo uma certa unidade reflexiva, uma determinação dobrada sobre o ser, em suma, 
alguma coisa $(\tau \iota)$ que se demarca de outra(s) pela diferença de si própria relativamente ao resto. O Uno, o Bem último de que Plotino faz o cume da sua ontologia é auto-suficiente e autárquico: uma vez que o Bem não tem necessidade nenhuma, nele não se pode dizer que haja uma qualquer urgência de unidade $(\tilde{\varepsilon} v \quad \varepsilon \iota v \alpha \iota)$ - a entidade

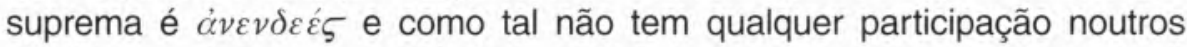
níveis superiores da realidade metafísica. Esta autarquia do Uno significa antes de mais uma ausência de predicados que the possam ser adequados: uma vez que o Uno não tem uma unidade determinada, Plotino refere que o Bem Supremo não tem necessidade sequer de si próprio: o Uno não carece de uma unidade porque em última análise ele é a última fonte de todos os predicados, ele é o Uno e portanto a própria possibilidade de unidade dos entes. Não necessitando de nada, de igual modo não deseja coisa nenhuma, nem substância $(\tau \iota)$

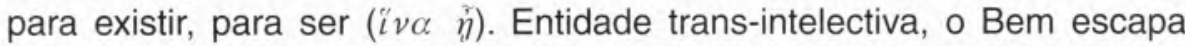
a todas as determinações do ser, do devir e do pensar: ele é sem essência, sem pensamento, sem auto-conhecimento e numa auto-suficiência despojada de tudo que está antes do ser, e que nesta medida é a grande origem da processão dos seres numa circularidade de uma eterna auto-geração na pura liberdade de não estar sujeito a nada. Nada possuindo, nada carece ou procura: o Uno super abunda em direcção a alteridades relativas, revirando-se para o seu princípio contemplando-o, detém o fluxo da sua constituição na medida em que se volta para si mesmo ${ }^{(2)}$. Esta suspensão da génese da alteridade, numa conversão pela qual contempla o seu princípio, torna-o ao mesmo tempo ser e intelecto. Será posteriormente esta hipóstase do Uno, o Intelecto que, permanecendo imóvel como a entidade superior, difundirá também a sua múltipla potência gerando simultaneamente uma forma, uma imagem ( $\varepsilon \dot{i} \delta \circ \varsigma$ ) de si mesmo: a alma ${ }^{(3)}$. Na verdade esta coloca-se entre o limite superior da inteligência intuitiva e contemplativa, suspensa ela própria de um trans-noético contacto com o Uno e o limite inferior do supremo Bem que é a natureza sensível. O que é particularmente subtil na ontologia de Plotino é justamente este desdobrar de todas as entidades numa real e autêntica duplicidade de possibilidades metafísicas: se algo se dirige para outra coisa, não podem restar dúvidas de que a sua forma, por muito inferior que seja traz em si uma totalidade das possibilidades sempre em aberto dos horizontes possíveis da realidade - natureza sensível, alma, intelecto, Uno - e neste sentido cada uma das estruturas desenrola-se numa teia de dependências dinâmica, harmonizada não tanto segundo uma 
fixação ontológica ensimesmada e entificada num Ser quiçá parmenídeo, mas ao invés mais inclinada para um afloramento de carácter mais odológico que se pauta em suma mais por uma teoria ontológica autenticamente odisseica da auto-constituição do Bem supremo em todos os planos metafísicos superiores e inferiores ${ }^{(4)}$. Mas em Plotino esta duplicidade de possibilidades espelha-se igualmente na própria estrutura profunda da sua ontologia: por um lado, de um certo ponto de vista é certo que temos uma entidade suprema, um ponto-de-fuga metafísico a partir do qual toda a realidade e manutenção dos entes se torna possível; todavia há ainda que ter em conta toda uma linguagem da $\tau o ́ \lambda \mu \alpha$ : toda a existência está de facto harmonizada numa cósmica inter-relação que se dirige para o Bem por natureza, contudo de outro ponto de vista toda a existência dos entes parece depender de uma ideia de mal-original reconduzível à audácia da individuali-

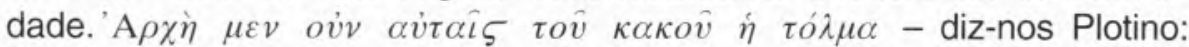
tal como surge de um lado a geração através da abundância do Uno, por outro lado e complementarmente, emerge esta ideia de que ainda assim em simultâneo, a audácia, a impertinência rebelde e insistente numa espécie de egoísmo metafísico é a causa essencial da separação dos entes em identidades cindidas do todo ${ }^{(5)}$ e da própria estrutura ontológica de toda a realidade plotiniana ${ }^{(6)}$. Aqui, precisamente neste aspecto, subjaz uma das questões que nos parece mais premente. Hans Jonas, em "The Soul in Gnosticism and Plotinus", relevou bem o que pensamos quando na introdução ao seu artigo enfatiza o facto do texto plotiniano estar desde a origem eivado de uma mistura constitutiva de ontologia e 'drama'(7).

A entidade suprema da metafísica de Plotino é a plenitude. O cume de toda esta construção metafísica é bem conhecido: seguidamente a estes dois tipos de participação enunciados, vem a participação dos entes no Uno ou no Bem. No curto trecho que analisamos já vimos que Plotino fala num registo absolutamente geral: se alguma coisa $(\tau \iota)$ não dirigir a sua actividade para outra e se ao mesmo tempo transcender todos os entes e em simultâneo todos eles dirigirem ao invés a sua actividade para ele, então essa coisa só pode ser o Bem, a entidade suprema através da qual todos os seres podem - e desejam participar no Bem. Pode-se falar sem dúvida alguma de um verdadeiro escalonamento detalhadamente proporcionado de participação no principal vértice da metafísica plotiniana: em VI, 1, 25 fica por exemplo bem claro que o ratio de unidade é equivalente ao ratio de ser - a quantidade de ser iguala a quantidade da unidade e vice-versa. Mas 
aqui e tendo também em conta a passagem sobre a qual nos debruçamos principalmente, não é a unidade que desce do Bem que dá unidade a um ente, mas é justamente a procura do Bem por parte dos seres que thes confere a devida unidade ${ }^{(8)}$. Os entes participam do Bem enquanto o desejam ou dirigem a actividade deles no seu sentido. O Bem é a $\dot{\alpha} \rho \chi \grave{\eta} \kappa \alpha i \quad \tau \dot{\varepsilon} \lambda o \zeta$, a origem e o objecto não posicionado, não teticamente localizado, que todos os entes na sua meIhor parte procuram e desejam. O melhor procura o seu semelhante desenvolvendo activamente a possibilidade de absoluto que traz em si próprio: através da actividade do que em si trás de melhor, cada ente aproxima-se do Uno na exacta medida em que o conseguir realizar no seu interior. $O$ desejo do Bem em Plotino, e nomeadamente na passagem sobre a qual nos debruçamos, parece-nos que se situa no plano da alma e, claro, na esfera da condição humana. O que caracteriza fundamentalmente o melhor da composição alma-corpo, o que caracteriza melhor esta comunidade nada pacífica é o desejo de superação do fenoménico em direcção à procura não apenas da beleza, enquanto suposto objecto do desejo e de fruição última do aglomerado alma-corpo, mas o Uno como fonte final do inteligível. Este desejo do Bem, do Uno enquanto supremo objecto do desejo humano, é suscitado pela sua presença na alma como uma vida maior de onde aliás procede o seu poder de viver. É absolutamente inerente à alma o seu desejo por aquilo que a possibilita: originária e constitutivamente animada de forma erótica pelo Bem, o desejo de pertença do que deseja ao desejado e a respectiva presença do desejado no desejo é o verdadeiro propulsor desta espontaneidade desiderativa. René Arnou, em Le désir de Dieu dans la philosophie de Plotin, explora bem este aspecto da filosofia plotiniana: a espontaneidade deste desejo através do qual a alma se encontra numa relação directa com o Bem dispensa a dialéctica metodológica das belezas sensíveis do Banquete de Platão - ao invés, em Plotino, neste jogo que temos vindo a explorar do macrocosmos contido nos múltiplos microcosmos ${ }^{(9)}$ do mundo natural, a presença em si da plenitude nas coisas, bem como o constitutivo e paradoxal desejo dela, excedem o fenómeno particular e contingente, determinando, conforme o vigor da memória, a conversão das almas ao Bem. Consubstancial à alma - conforme aliás a arcaica tradição pictórica e narrativa da união entre Eros e Psique - este amor ou desejo do Uno prende-se com a sua condição de ser dele procedente e de ao mesmo tempo, em último reduto, ter em si próprio a presença transcendente do Bem. Para Plotino «a alma nasce como 
uma virgem seduzida por uma promessa de casamento" e, vinculada depois pelo "amor de um ser mortal» $(\mathrm{VI}, 9,9$.) que a cinde violentamente de seu pai, reconhece e rejeita essa mesma rebeldia do desejo - que habitualmente estrutura a vida dos mortais - por objectos caducos, fantasmas instáveis que nunca saciarão o desejo, também dela constitutivo pela origem, de se re-ligar ao Uno. No campo da união do ente com o Bem, a múltipla referência durante toda a obra de Plotino a uma ovvovoía - desta passagem formalmente elidida - aponta a natureza última da experiência cume dos seres: tal como os amantes procuram assemelhar-se de corpo e alma aos amados para em nada Ihes serem inferiores e poderem assim unir-se a eles, a alma, inflamada por esse desejo do que transcende toda a determinação morfológica e inteligível, surge claramente marcada por um matiz metafórico (i.e., o campo da experimentação do pensamento, ốov, na terminologia plotiniana) erótico e espiritualmente enriquecido. A $\varepsilon \phi \varepsilon \sigma \iota \zeta$ abre o campo não tanto para uma arquitectura ontológica, mas transita para uma fenomenologia do desejo que incorpora a própria experiência do Uno. Todas as coisas podem aproximar-se do Bem de duas formas: assemelhando-se a ele, ou dirigindo a sua actividade na sua direcção.

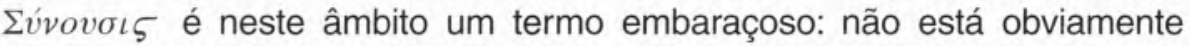

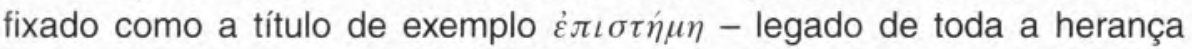
platónica que Ihe subjaz. Plotino em III, 7, 7, 3 questiona de forma

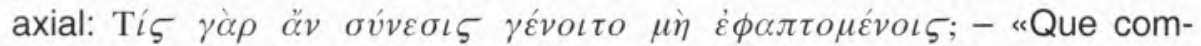
preensão/entendimento/intuição pode haver (i. e. do Uno) se não em

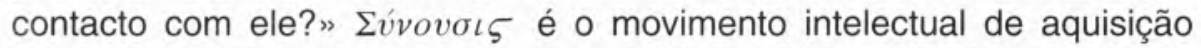
de alguma coisa não completamente ainda discernido, é o modo de entendimento do inexpressível, do Bem último e absoluto. Sendo o fito principal da alma recebê-lo, "ela não deve guardar para si nem bem nem mal" preparando um esvaziamento interior que tenha como resultado um assemelhar-se à indeterminação do Uno, ou dirigindo-se para um contacto em tudo semelhante ao do "amante que se quer confundir com o amado" numa claríssima alusão à união sexual (VI, 7, 34; VI, 9, 9) ${ }^{(10)}$. Neste instância, diz-nos Plotino, esquecem-se "todos os espectáculos" numa presença que "enche a alma» (VI, 7, 35), mas que só pode ser reconhecida como uma radical transformação da percepção. Paralelamente a esta possibilidade, contrastam as palavras de Plotino relativamente à descrição do encontro com o Uno: o carácter deste encontro, já atrás o vimos, mais do que um conhecimento no sentido comum e que se constitua na relação representativa entre um objecto e um sujeito, revela-se um contacto íntimo e silencioso ( $\dot{\varepsilon} \pi \alpha \phi \dot{\eta})$ 
cujo significado relembra não por mero acaso todo um carácter sensual e erótico do encontro entre o homem e o ente superior. Tocar, apalpar, roçar, acariciar - são tudo termos que traduzem esta relação fundamentalmente táctil que Plotino não tem qualquer pudor em colocar além da platónica visão do Bem (Platão, República 504e), identificando esta ainda com um 'conhecimento racional'(11). Quanto à alma individual, Plotino ao mesmo tempo que exorta a um regresso interior do indivíduo ao seu âmago, dispensa em última análise o já muito glosado preceito délfico e socrático do "conhece-te a ti mesmo", uma vez que tal só se aplica aos seres que em si trazem uma multiplicidade ignorante do seu núcleo. O encontro com o Uno pode espelhar-se esquematicamente no seguinte procedimento:

1) Em primeiro lugar é necessário à alma retirar-se de tudo o que

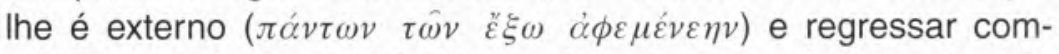
pletamente à sua interioridade $(\delta \varepsilon \iota \quad \dot{\varepsilon} \pi \iota \sigma \tau \rho \alpha \phi \hat{\eta} v \alpha \iota \quad \pi \rho \grave{\zeta} \tau \grave{o}$

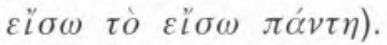

2) Entramos no passo da eliminação do conhecimento na alma.

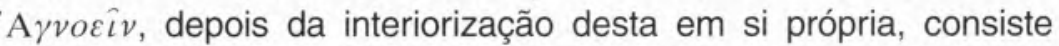
na supressão de todo o conhecimento das coisas:

a) no seu ser acidental e no seu modo de funcionamento;

b) nas suas formas $(\varepsilon i \delta \varepsilon \sigma \iota v)$.

3) Por último, a alma deve ignorar-se a si mesma para que então se possa abrir à visão/à companhia do Uno. A alma deve tor-

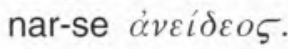

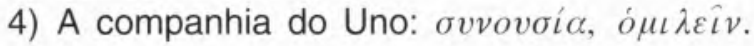

A resposta de Plotino à problemática metafísica que o afecta não é em nada inocente: o que observamos neste aparato monumental de estruturas conceptuais postuladas e de complexos processos ontológicos não é algo que apareça sem que concorram para isso diversas razões. O Uno, o Bem, o Intelecto e a Alma na metafísica de Plotino são pontos de partida para resolver todo um conjunto de problemáticas inerentes à tradição de que ele é herdeiro. São categorias explicativas, são princípios de explicação, são grelhas de sentido do modo como a realidade se constitui e se processa. Os próprios termos que aplica são marca disso mesmo: quase sempre o leitor é advertido de que estamos no campo da formulação metafórica, do oíov como de resto também já referimos. Todo este processo de ascensão da alma, do próprio dimanar do supremo Bem para a criação dos entes e da 
consequente rebeldia destes denuncia o que referimos: Plotino, na construção deste edifício está sem dúvida e incondicionalmente inserido numa longa tradição filosófica reconduzível, pelo menos, até Parménides e ao seu famoso poema. A solução que apresenta para a resolução do problema eleático no fragmento B3 é distinta da resposta platónica ou aristotélica: o que vemos logo numa primeira aproximação ao texto plotiniano é sem dúvida um género de discurso que embora não pareça, está sub-repticiamente e intimamente articulado com uma dramaturgia estrutural do ponto de vista metafísico que se exprime no carácter metafórico recorrente e que o anima teleologicamente. Apesar do seu escasso recurso directo a uma certa tradição religiosa da sua época mais exterior e folclórica, apesar do seu quase nulo recurso até a um discurso de carácter mais teológico, verdade é que toda a sua construção metafísica assenta sistematicamente num tratamento das questões fundamentais, num registo de discurso metafórico-mitológico.

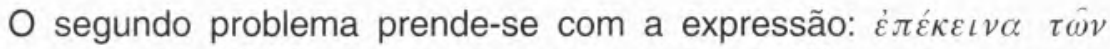
$o ́ v \tau \omega \nu$ - se em Platão estamos perante uma metáfora que procura resolver todo um conjunto de questões, o mesmo se passa com Plotino: os três principais princípios, $\dot{\alpha} \rho \chi \alpha i$, pretendem ser o ponto de partida de explicação de todos os fenómenos da realidade. Do Uno não procede uma forma de unidade: o Uno, por não ser compatível com nenhum tipo de complexidade, não é, como aliás já o vimos, predicável com verdade de nenhum tipo de predicados (III, 8, 10); o Uno é de facto o primeiro princípio de toda a metafísica de Plotino e, contudo, dele não se pode dizer sem cuidado que seja $\delta$ d $\theta \varepsilon o ́ \varsigma$. No texto do filósofo egípcio, o termo $\theta \varepsilon o ́ s$ refere-se regra geral a algo com um real e maior poder que um mero homem: o investimento no termo $\dot{\alpha} \rho \chi \dot{\eta}$ de atributos "pessoais" à maneira das tradições profundas da consciência religiosa ingénua ou das religiões reveladas está muito longe da realidade aqui presente. Para Plotino, e virtualmente regra geral para os filósofos gregos pagãos, a personalização total do primeiro princípio é um passo complexo e que só poderia eventualmente emergir mediante um determinado tratamento filosófico que o permitisse: no contexto do nosso autor, o Uno surge sem dúvida constituído como a entidade investida de uma infinitude que the permite ser não só a causa da existência dos entes, como da sua manutenção existencial - colocado para lá da possibilidade de o conceptualizar correctamente, na sua simplicidade radical, o Uno, o Bem supremo, a sua 
essência é idêntica à sua existência. Enquanto o Uno é a causa da existência de tudo quanto existe - incluindo de si próprio: aǐt ıov $\dot{\varepsilon} \alpha v \tau o \hat{v}$ - refere Plotino -, enquanto o intelecto é o princípio e a causa de toda a essência, de toda a ov́ía, o ponto crucial desta narrativa metafísica do Uno é justamente ele ser a causa eficiente do existir dos entes. A primeira actividade, a actividade do que não se dirige para lado algum excepto para si mesmo no processo auto-constitutivo que já realçámos, é uma actividade sem essência que causa o ser

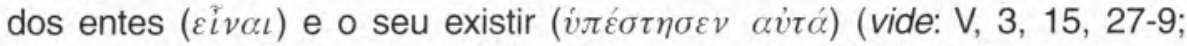
II, 4, 5, 25-6; III, 8, 10, 1-2; IV, 8, 6, 1-6; V, 3, 17, 10-14; V, 5, 5, 5-7; VI, $7,42,11 ; \mathrm{VI}, 9,1,1-2)$. O Uno é a causa primária da existência de todas as coisas num molde de uma série de causalidade per se: A é a causa de B e de C, onde por sua vez, B é a causa instrumental de A. O Uno é a causa eficiente do intelecto e da alma, ele é o princípio sem predicados, o princípio puro e simples da eficácia, é a última explicação ou causa de tudo quanto tem existência, essência ou vida ( $\mathrm{VI}, 7,13,28-42)$. O intelecto por sua vez é a causa instrumental do Uno: ele é a causa primária das essências dos entes, enquanto a alma é o princípio do movimento encarnado, seja ele dos indivíduos, seja ele do universo e da sua alma universal. Plotino usa sempre o termo ह̌ $\phi \varepsilon \sigma \iota \varsigma$ para designar a relação de todas as coisas colocadas inferiormente ao Bem: o desejo que não seja reconhecidamente de si próprio denuncia sempre uma alteridade última daquele que deseja. $\mathrm{O}$ intelecto deseja sempre o seu bem: contemplar as formas não oblitera de maneira alguma a distinção entre ele próprio e o Uno - a intelecção é a actividade do intelecto, e tal como nos animais, nas almas encarnadas, o desejo de unidade é o resultado último das partes que os constituem.

\section{c) Comentário Crítico, I. 7. 1, 21-29}

Já atrás, em I, 7, 1, 19, Plotino se tinha referido ao Bem com o termo $\tau \dot{\alpha} \gamma \alpha \theta \dot{o} v$ : esta terminologia especial para o supremo Bem, usada pelo filósofo egípcio, com o artigo e crase, é explicada pelo próprio em VI, 7, 38, como uma tentativa de evitar a cópula e o artigo com o género devidamente definido. Não se tratando de uma outra hipóstase metafísica, Plotino assinala até neste subtil aspecto como esta transcendência imanente e omnipresente, esvaziado o pensamento de todo objecto degradado na diferença sensível ou inteligível, se furta ao hori- 
zonte meramente ontológico - como atrás já o relevámos - para se situar num 'toque' trans-sensível e trans-inteligível mais próximo do verdadeiro contacto com o único e total centro infinito da realidade. Do Uno tudo depende: ele é a condição de possibilidade de existência dos entes e por esta mesma razão, Plotino não se afadiga de o dizer: ao Uno tudo aspira. A metáfora do círculo, do seu centro e do seu perímetro é introduzida aqui nesta passagem pelo nosso autor não por mero acaso: o centro do círculo bem como o seu perímetro têm um papel importante no que diz respeito à clarificação da situação metafísica das entidades transcendentais e principais. Como Armstrong o refere $^{(12)}$, ou Krämer ${ }^{(13)}$ aponta, a metáfora do círculo é amplamente usada por Plotino para ilustrar as relações da alma com o centro dos centros. Para esclarecer a importância do aparecimento desta metáfora, no tratado $\mathrm{V}, 1,11$, o filósofo egípcio explica-nos: ' $\varepsilon$ v $\pi \circ \lambda \lambda o i \varsigma ~ \alpha \hat{v}$

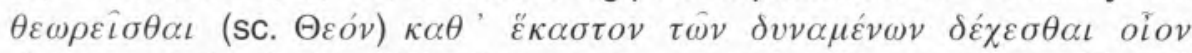

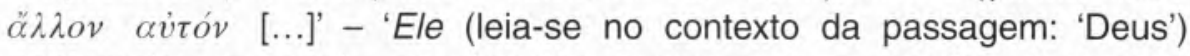
contemplou em cada um daqueles capazes de o receber como que um outro'. Pese um pouco o aparente equívoco da terminologia, mas questionamo-nos se em rigor não se poderia ler esta parte final da referida passagem da seguinte forma: como que um outro 'alter-ego'. A questão é: até que ponto esta entidade suprema e a alma terão um vínculo de unidade, como coincide ou não a alma com este Bem e quão completa ou incompleta será esta unidade entre ambos? Plotino tem para nós uma resposta conclusiva e de suma importância sobre este assunto: a melhor parte de nós mesmos não só está em contacto com o Bem, mas está de facto com Ele e depende dele por termos

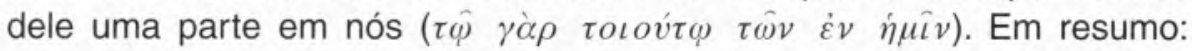
cada um de nós está estabelecido em Deus, tal como o perímetro de um círculo depende do seu centro: não há só uma tendência de Deus para nós - por ser o fundamento último de toda a $\phi v ́ \sigma \iota \varsigma$, de todo o existir e do inexorável desejo de incremento e de permanência da vida - mas de nós, dos membros que perfazem a linha da circularidade. O centro transcende o somatório dos pontos participantes em todo o raio do círculo: onde o fundamento da circularidade puder ser reconhecido, os seus limites ( $\pi \dot{\varepsilon} \rho \alpha \tau \alpha)$ estão igualmente presentes e dependem em último reduto do centro que os determina. Metaforicamente falando, o Intelecto, na metafísica plotiniana, é claramente o centro do círculo, a parte mais excelsa que recebe o Bem numa peculiar forma de identidade entre os dois onde ainda assim a Suprema Entidade permanece sempre em si numa paradoxal não-coincidência. 
O Uno é o outro, o eu superior daquele que o recebe: parece sem dúvida, como de resto o apontou Meijer ${ }^{(14)}$, que Plotino está quase a

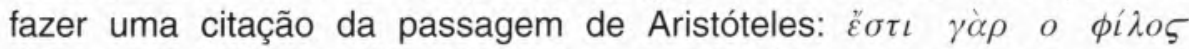

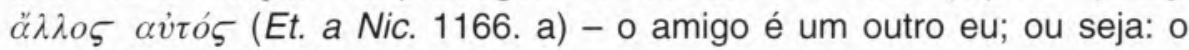
amigo de alguém é como um outro eu de mim mesmo.

O Uno, o Bem é o centro do intelecto e da alma: e enquanto o intelecto está geneticamente e desde o início na proximidade do fundamento último da realidade, a alma, se virada para o que é melhor, aspira à mesma proximidade. A noção de circularidade aqui introduzida por Plotino é claramente uma paráfrase do Timeu (43e) e do Fedro (249c) de Platão: a autêntica centrologia ${ }^{(15)}$ surge como uma combinação entre o movimento circular do todo em torno do Uno, e em simultâneo do movimento centrípeto de todas as coisas e actividades, que é expressão do poder causal do Uno.

A metafísica de Plotino constrói-se não só fazendo uso de uma linguagem mitológica: ao invés, constitui-se nuclearmente como um tipo de discurso que se articula e anima por uma razão mitológico-metafórica. No seguimento desta figura da circularidade, o texto plotinano em VI, 9, 1 chega até a descrever uma imagem que quase nos remete para o imaginário da consciência salmódica: uma vez o intelecto direccionado para o centro da realidade profunda, a alma coloca-se inexoravelmente numa posição de coincidência com este fundamento último, e neste sentido Plotino sugere até a imagem de que na verdade absoluta os entes "dançam" ( intelecto e do ser, em suma, da causa do Bem último e da raíz da alma. П $\eta \gamma \eta \dot{~(f o n t e) ~ e ́ ~ t a m b e ́ m ~ u m a ~ i m a g e m ~ r e c o r r e n t e ~ n o ~ t e x t o ~ d o ~ f i l o ́-~}$ sofo egípcio: concatenado à afamada teoria da emanação e do fluxo, Plotino reitera recorrentemente a ideia de uma dependência total dos entes na malha ontológica procedente da origem. A comparação que Plotino usa é esplêndida: equiparando as nossas almas com um coro

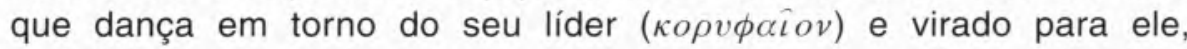
metafisicamente a vida humana, ou pelo menos, a melhor parte dela, tem em si inscrita a possibilidade e o dever ético-ontológico da atenção. Gravitando em torno do Bem, uma vida sem o seu reconhecimento é uma vida sem Deus ${ }^{(16)}$ ( $\alpha \varepsilon v v$ $\left.\theta \varepsilon o \hat{v}\right)$, é como uma sombra ou

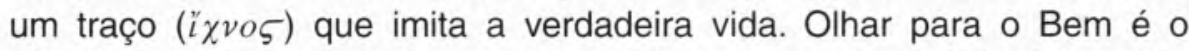
objectivo, o único descanso para a alma e por conseguinte é também

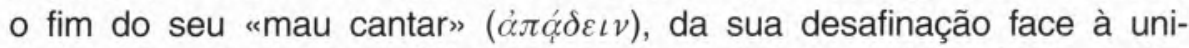
dade última dos entes. "We really are dancing around the God" - diz-nos Meijer numa passagem bem ilustradora, julgamos, do conjunto 
enriquecido de metáforas que encontramos em Plotino. Círculo, dança, luz - são metáforas dramáticas que se opõem a outras do mesmo carácter, mas desta vez negativas: queda da alma, ilusão/rebeldia e esquecimento são a constelação dramática explicativa da metafísica de Plotino que por sua vez depois contrasta bem com as metáforas formais que formam a grande estrutura do pensamento plotiniano: o Uno, o Bem, Deus, o intelecto, e a alma são no fundo os principais dispositivos explicativos sobre os quais gravitam depois todas as narrativas dramáticas que têm uma função eminentemente explicativa dos fenómenos da realidade. Em Plotino encontramos, como de resto o atesta em parte também a passagem sobre a qual nos debruçamos, toda uma teoria da luz, uma verdadeira fotologia: o sol, à maneira platónica, é também o paradigma $(\pi \alpha \rho \alpha \dot{\delta} \delta \iota \gamma \mu \alpha)$ por excelência do que temos vindo a desenvolver nesta parte do comentário: colocado no centro da vivência dos seres, é desse centro fundamental que dependem todos os entes, quer estes o reconheçam ou não. "Se estamos sempre em seu torno, não olhamos sempre para ele" (VI, 9, 8): o problema reside não numa distância por hipótese real do Uno e nem sequer de um afastamento real dos seres, mas toda a questão - e tal como nos aparece reflectido na imagem do coro já referida - está no desvio do olhar, bem como no simultâneo não reconhecimento do carácter ilusório das separações, das distâncias, enfim, da fictícia alteridade de si e do seu objecto. O que é mais próximo passa assim a ser o mais distante e se afinal nunca estivemos noutro lugar senão no centro de nós próprios e no centro do todo, o que sucede não é tanto um "afastamento de lugar" (VI, 9, 9), mas da intelecção que, incapaz de se redimir no amor congénito ao Uno de que é feita, se exila no mundo da experiência, das teias intra-mundanas do mundo e da pulsão centrípeta que parece animar o Bem primordial na sua espontaneidade criativa e produtora. Ver, para Plotino, nada mais é senão «inundar» os olhos de luz - mas isto, note-se bem, não no sentido de uma quiçá leitura habitual das nossas consciências em que a luz aparece como um meio para a visão de determinado objecto; neste caso, em Plotino, a visão emerge como a luz em si mesma. Só a luz pode engendrar os objectos que possibilita e na senda deste caminho, por ser a própria visão, a luz quando sobre si mesma se debruça só a si mesma se pode ver. No tratado VI, 9, 9, Plotino não nos deixa dúvidas sobre esta problemática: o intelecto uma vez esvaziado e virado sobre si mesmo vê de rompante o Bem sem saber de onde terá emergido esta visão. $O$ intelecto inunda-se de luz e esta não revela 
ou des-oculta qualquer coisa - pelo contrário, a visão é a luz em si mesma. No Bem não há duas coisas, i. e., não existe uma coisa que existe e que é revelada através da luz, e por outro lado também não existe de igual modo alguma coisa que pense e, concomitantemente, seja pensada. É no plano deste paradoxo, do contacto último sem sujeito nem objecto, que Plotino parece apontar o objectivo último do humano, do mundo natural e do seu imo mais profundo: a «epopeia mística que são as Enéadas" "(17) enquadra-se sempre na ideia que temos vindo a relevar: o excesso que transcende toda a dimensão ôntica, ontológica, ontonoética e toda a transcendência metafísica do universo e dos seus múltiplos graus de verdade. Extrinsecamente designado como Uno, Bem, Pai, Primeiro, Origem - a grande diferença de Plotino relativamente ao seu mestre, Platão, é justamente a subtileza da transformação deste conceito primitivo do ponto de vista explicativo para a construção de todo um edifício metafísico: para o ateniense a "forma" do Bem, tal como é representada a partir dos diálogos da maturidade é o sistema da unidade e finalidade de todas as formas, expresso pelas suas características eidéticas (perfeição, imutabilidade, etc...). Em 509b da Républica, a metáfora do Sol é encarada só aparentemente de forma semelhante à que o texto plotiniano faz jus: se para Platão, o Bem é a unidade orgânica de todas as formas estruturalmente ordenadas conforme as suas características, para Plotino esta entidade última da metafísica aparece intimamente dissolvida numa consciência religiosa. As consequências da identificação do Uno com o Bem, a fusão destes com a consequente identificação da totalidade com o fundamento último da realidade e a sua posterior divinização, são as bases para uma dramaturgia teleológica da ontologia.

\section{Metafísica plotiniana e mitologia - o substracto religioso}

i) O dramatismo metafísico(18) de Plotino - uma ontoteologia do metafórico: a consciência religiosa

O que nos importa nesta fase da reflexão relevar é justamente este carácter religioso que constitui os grandes filões do pensamento plotiniano como grande comentador de Platão e Aristóteles, e em paralelo, como grande introdutor de uma magna ontoteologia no pensamento filosófico que fará história nos trâmites da história das ideias até ao mundo contemporâneo. As questões das influências histórico- 
-filosóficas são prementes, todavia o que nos importa relevar não se prende totalmente na contingência histórica: ao invés, o que pretendemos é tentar escrutinar não só os grandes motivos que subjazem à forma própria de raciocínio do pensamento de Plotino, como de identificar as principais estruturas específicas da consciência religiosa. Para o efeito vamos debruçar-nos essencialmente apenas sobre três aspectos que nos parecem absolutamente basilares na concepção geral da sistemática metafísica do filósofo egípcio. 1) A questão do Uno e do Bem, ou seja, da postulação metafísica de um certo imo último da realidade que não só permite e possibilita a existência de todas as realidades sensíveis ou inteligíveis, como determina a funcionalidade e a actividade destas em direcção a si mesmo; 2) o problema da alteridade do Uno e da cisão - a dualidade e o abandono teimoso na rebeldia da vida: o tema do niilismo e do mal na consciência religiosa; 3) o desejo do Bem: do negativo à circularidade aberta para o espaço ético.

1) No plano do estudo da fenomenologia das religiões, Rudolf Otto, na sua obra Das Heilige - Über das Irrationale in der Idee des Göttlichen und sein Verhältnis zum Rationalen, começa o seu estudo debruçando-se justamente sobre uma questão que nos parece constitutiva do que estamos a tratar: fazendo uma leitura do sagrado e dos elementos mais característicos do numinoso, Otto, ao longo de toda a sua obra, procura relevar sempre a dialéctica que preenche toda a experiência religiosa. Será que esta se coaduna com a leitura plotiniana? Se atrás tivemos a preocupação de reconduzir o trabalho filosófico de Plotino à meditação e experiência religiosa e teológica, será que este matiz que realçámos se conforma com o que teólogo alemão protestante avança na sua obra? Para Rudolf Otto o elemento fundamental que determina qualquer experiência religiosa gravita em torno daquilo que ele denomina do 'sentimento do estado de criatura'; evidentemente, Otto, à partida coloca-se na posição de um exegeta do fenómeno religioso judaico-cristão e neste sentido, pelo menos aparentemente, parece estabelecer-se numa perspectiva diferente do tipo de discurso que aqui abordamos. Mas em rigor, se nos atentarmos sobre o texto de Plotino, rapidamente ficamos com a noção de que o filósofo egípcio está nitidamente a reflectir nas mesmas «águas" que toda e qualquer consciência religiosa. Começando pelo fim deste breve trabalho de meditação, não é nada de estranhar a emergência de uma teologia solar como a que atrás tivemos oportunidade de referir e comentar, embora não esteja de facto bem patente a emoção profunda 
de terror, de arrebatamento, de um mysterium tremendum que Otto reconduz ao primórdio do fenómeno elementar da consciência religiosa. O sentimento do sinistro e o arrebatamento emocional do apagamento perante a majestas do sagrado é a primeira manifestação e a origem de todo o desenvolvimento da imaginação mitológica e da história da religião; Plotino, embora num registo de alguma objectividade filosófica, não escapa de maneira alguma a uma leitura deste tipo. $O$ elemento numinoso é um lugar comum no seu texto: o Uno, o Bem é o eixo axial de todo o movimento especulativo: escapando ao meramente inteligível, encaixa-se perfeitamente na categoria do inefável. Esta categoria explicativa e primitiva em Plotino é sem sombra de dúvida de uma natureza teórica tal, que sobre ele não se podem desenvolver conceitos adequados: a absoluta superioridade deste tremendo que constitui o Uno pode perceber-se na subtil dialéctica que se encontra profusamente trabalhada no texto do filósofo do século III d. C. Por um lado, a metafísica de Plotino coloca o ente numa posição de total afastamento do último Bem, instalado na total e humilhante cisão daquilo de que em último reduto procede, e por outro lado, introduz em simultâneo não só uma ideia de dependência ontológica e metafísica entre os entes sensíveis e inteligíveis que constituem a realidade, mas de igual modo introduz a noção de uma causalidade metafísica da existência dos seres. O carácter ambíguo da grande lição de Plotino espelha-se justamente nesta duplicidade anfíbia da metafísica especulativa por ele desenvolvida: partindo de Platão - e sem dúvida de uma firme presença de Deus nos diálogos platónicos, de toda a moldura mítico religiosa da teoria das formas e do próprio significado da criação divina do cosmos para o mestre ateniense -, o texto plotiniano insiste numa inacessibilidade actual das almas à verdade última da realidade, e em paralelo na paradoxal possibilidade de acesso a essa mesma realidade claramente localizada numa categoria metafísica do

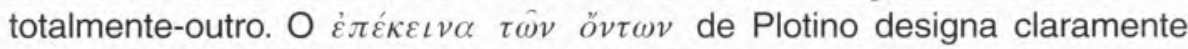
uma realidade cuja qualidade particular é em simultâneo o da extrema oposição do objecto numinoso relativamente ao ente, e a da possibilidade radical de união e reabsorção do Uno em si mesmo: não restam dúvidas de que o Bem plotiniano se encontra inserido e é resumo dos três graus de evolução interna do carácter mirum do numinoso:

a) ele é o "totalmente-outro", o inatingível e o incompreensível através dos modos próprios da consciência; o Uno escapa necessariamente ao princípio inteligente da realidade porque é transcendente em relação a todas as categorias. 
b) o numinoso de Plotino não ultrapassa apenas as categorias da inteligência: dele nada se pode predicar, como de resto vimos, mas de igual modo ele é o local por excelência onde se suprimem as categorias, tendo com elas relações de oposição - e aqui estamos evidentemente no domínio do paradoxo.

c) por último, o Uno em Plotino, como princípio explicativo que ocupa na estrutura metafísica do filósofo, está muitas vezes caracterizado sob a forma da antítese e da irredutível antinomia.

O carácter profundamente religioso da metafísica de Plotino exprime-se justamente no filão arcaico das categorias mentais de que faz uso na sua construção teórica: o recurso a uma realidade central que é ponto de convergência de todos os entes, o recurso à ideia de uma entidade suprema que é a causa existencial e o garante da actividade de todos os seres, reconduz-se ao conteúdo qualitativo do fascínio que habitualmente incorpora toda a espécie de sentimento ou pensamento religioso. A dialéctica do mistério e do sentimento do estado de criatura, tal como nos é descrito por Rudolf Otto, emerge de forma clara na concepção plotiniana segundo a qual os entes dirigem a sua actividade para o Bem: «a criatura que, perante ele treme, se humilha e perde coragem, experimenta ao mesmo tempo o impulso de se voltar para ele e até dele se apropriar» ${ }^{(19)}$ - o elemento da enormidade do Uno contrasta com uma representação racional dele na construção metafísica de Plotino(20). A dialéctica da apresentação do Uno recorre a um discurso de cariz fortemente pedagógico, como que num ambiente pelo menos atreito ao espírito iniciático e com traços acentuados de exaltação à necessidade do reconhecimento desta realidade última: ao mesmo tempo que o filósofo egípcio coloca a ideia de um Uno distanciado na cisão da diferença dos entes, Plotino estabelece uma metodologia descritiva de uma metafísica que pretende ser uma $\sigma v \mu \pi \varepsilon \rho \iota \alpha \gamma \omega \gamma \dot{\eta} \tau \varepsilon \dot{\varepsilon} v \eta$ $\tau \hat{\eta} \varsigma \quad \psi v \chi \hat{\eta} \zeta$ : anuncia-se o caminho de um certo ver que exige o esvaziamento do olhar natural da alma para o reconhecimento da realidade última. $O$ excesso do sumamente fascinante é o que está "acima e para além do nosso ser», todavia, desde o princípio dos tempos esteve sempre "escondido no fundo da nossa natureza» ${ }^{(21)}$. No reconhecimento de que o finito, de que a finitude dos entes se produz justamente através da infinitude do Uno, Plotino está a construir uma onto-teofania teocríptica que se fundamenta por sua vez numa arqueo-escatologia do Bem. O Uno é o princípio e fim absoluto de todos os entes: ele é o drama que se desvela em entes nas 
vicissitudes de uma pluralidade a ultrapassar. O coração da metafísica de Plotino nasce e desenvolve-se tendo como motor principal os três aspectos que temos vindo a desenvolver: em primeiro lugar a postulação de uma entidade superior que é o fundamento (existencial e funcional) último da realidade, em simultâneo a ideia de uma separação/cisão/produção desta origem relativamente aos entes, e em paralelo a (re-)construção metafísica de uma ideia tão cara à tradição europeia do regresso à origem ${ }^{(22)}$.

2) A questão levantada pela alteridade do Uno está directamente relacionada com o eixo principal dos conceitos sobre o qual está montada esta construção especulativa: ao mesmo tempo que o Uno é o absoluto além de toda a predicação, refira-se o facto de que também sobre o problema da alteridade é possível ter duas perspectivas. Uma, a do ponto de vista do Uno, que é o de uma geração excessiva por auto-negação da absolutidade infinita do Uno para uma espécie de maldita finitização de toda uma pluralidade; a segunda perspectiva encara o assunto do ponto de vista do ente: os seres constituem-se, como de resto também já atrás o referimos, por uma audácia da indi-

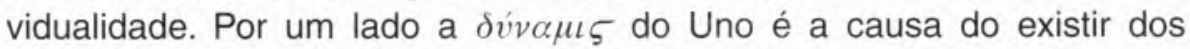
entes e do preservar $(\sigma \omega \zeta \varepsilon \iota)$ ontológico destes na existência. O poder criativo do Uno é justamente esta radicalidade de uma manência ( $\mu$ ov $\left.\eta^{\prime}\right)$ transcendente que ao mesmo tempo e paradoxalmente nunca

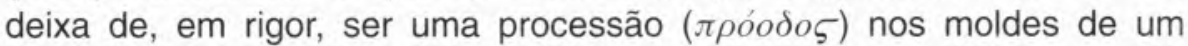
devir dinâmico orientado para si próprio, e do Bem, em última instância, sempre contíguo. Esta auto-génese, esta onto-teocosmogonia não estaria contudo completa se não estivesse consumada sistematicamente por Plotino na ideia de que, de outro ponto de vista, da perspectiva dos seres enredados na pluralidade do mundo e das relações sujeito/objecto, é necessário o capítulo do reconhecimento e da reaproximação à origem. A indeterminação do Uno é a potência de todas as determinações: o indiferenciado perfeito parece determinar e estabelecer os seres numa distância e na diferença posicionada da vida. Embora as partes tenham, como de resto vimos, encerradas em si o poder do todo, a dualidade e o abandono são o apanágio da alma que se encontra caída $(\dot{\varepsilon} \kappa \pi i \operatorname{\tau } \tau \varepsilon \nu \nu)$ na divisão, na cisão, na diferença ontológica. O dividido é o que está dividido e não dividido: $\mu \varepsilon \rho \iota \sigma \theta \varepsilon \hat{\imath} \sigma \alpha \iota$ $\kappa \alpha i$ ov $\mu \varepsilon \rho \iota \sigma \theta \varepsilon \hat{\imath} \sigma \alpha \iota$ (IV. 3, 17) - refere Plotino adensando o carácter antinómico tão característico do objecto numinoso das consciências religiosas: de outro ponto de vista, é a audácia $(\tau o ́ \lambda \mu \alpha)$ dos entes a 
raiz da outridade, do vir-a-ser, da vontade de independência. $O$ esquecimento da origem é o peso que condena as almas à sua queda e à angústia do cuidado auto-centrado na sua condição (IV, 3, 18). A fragilidade do condicionado, do imperfeito, do que existe e não tem o poder de actualizar a sua própria potência, do que não se pode realizar e efectivar em absoluto e infinito é o sinal do ente. Forma, multiplicidade una em organismo e multiplicidade meramente instalada na pluralidade das coisas é o que constitui a perspectiva da alma pesada e caída no esquecimento. Há toda uma dialéctica do peso das almas que desenvolve o programa mitológico-metafísico plotiniano: há toda uma ordem universal (IV, 3, 13) que ciclicamente floresce não só no peso das almas que se deixam arrastar por uma espontaneidade criativa tanto do Uno como delas próprias, para uma dormência na queda do esquecimento, bem como por outro lado no desejo resoluto (zeloso, em grego: $\pi \rho \circ \theta v \mu i \alpha$ ) de regresso à origem. A alma tem de operar um esvaziamento(23) de si e do que lhe é próprio, no sentido de assim se tornar mais leve para poder retornar ao Uno. Em suma, o problema da alteridade em Plotino, se interpretado sem a consciência do que de metafórico, mitológico, religioso e dramático está investido na constituição da metafísica plotiniana, torna-se impossível de compreender: na verdade a alteridade, a forma da alteridade, o simples poder 'haver outro' que não seja à partida o Bem último, faz profundamente parte desta narrativa, uma vez que se instala claramente no domínio da representação do lugar comum do niilismo e dos ciclos de decadência do mundo. A racionalização poderosa do numinoso é o traço fundamental da obra do filósofo egípcio - e isto não quer de maneira alguma dizer que com esta introdução do entendimento, das suas categorias e processos próprios de agir sobre o que lhe é dado, se tenha eliminado a categoria do sagrado no âmago mais profundo da sua obra. Embora disfarçado ou até, cremos, supostamente tornado visível num certo 'misticismo' vulgarmente atribuído ao filósofo pelos teóricos contemporâneos, o que importa relevar é que justamente este carácter profundamente religioso de Plotino não se prende de forma capital no uso mais ou menos inócuo que faz da mitologia folclórica da sua época, mas é a verdadeira essência da sua meditação. De outro ponto de vista que não seja o da excessividade produtiva do Uno, a ontologia de Plotino passa também por ser - como muitas cosmogonias pertencentes à história das mitologias e das religiões - uma metafísica da cisão e da separação abissal: a separação, no campo da consciência religiosa é uma metáfora comum da condição de pos- 
sibilidade para o sacrifício primordial da diacosmicização do indiferenciado em direcção à mesura, à identidade, à essência e por fim à vontade dos entes. A génese da pluralidade traz o espaço do sentir e da necessidade dos entes: vontade de isolamento e independência constituem a autêntica tragédia da vida e da angústia que lhes é inexoravelmente inerente. Desvinculados do todo, desmembram-se em partes na ausência do reconhecimento da união última do todo, lançando-se assim na determinação ontológica, na contraposição e oposição em que consiste o mundo terreno. Esta recusa do gratuito da absolutidade, afinal sempre presente em todas as partes do que existe, está também directamente relacionada com um lugar comum da consciência religiosa: pautada essencialmente por uma necessidade da mediação entre o sagrado e o profano, a ideia de uma rejeição da gratuitidade do absoluto funciona paradoxalmente como elemento propulsor para a resolução do dramatismo constituído na separação. Posteriormente o reconhecimento desta recusa primordial será a efectivação e resolução do negativo. Nesta metafísica da separação que subjaz ao pensamento de Plotino, mais do que ser o fruto de um incrível sincretismo e desenvolvimento não só do dualismo órfico-platónico, mas de igual modo de um niilismo característico do ambiente gnóstico que matizava a época do filósofo egípcio, importa ressalvar que na verdade, mais do que uma influência da contingência histórica e cultural da época, estamos perante um modo sem dúvida característico da consciência religiosa operar. No imaginário mítico-simbólico da consciência religiosa em geral, capital é o lugar que um conceito como o da separação/dualidade ocupa: articulado com toda uma robusta concepção de que ao mesmo tempo que a cisão é justamente o lugar da queda de qualquer coisa, e que com ela se torna regra geral possível o aparecer do mundo, toda esta questão parece desde o início constituir-se como um drama metafísico onde ao mesmo tempo que o centro da realidade mais profunda é a condição de possibilidade da sua própria alteridade, a própria pluralidade instaurada e que dele depende é um sintoma trágico da sua própria humilhação na morte dos entes. A determinação da separação, a cisão, a clivagem e queda são temáticas que explícita ou implicitamente são sempre pedra angular do que espiritualmente se produziu nas grandes traves mestras do pensamento religioso. Completamente incontornáveis são de facto as manifestações arqueológicas, pré-filosóficas e em boa verdade pré-mitológicas dos confins da espiritualidade europeia que assentam cabalmente sobre esta estrutura arcaica do pensar religioso e posteriormente, da reflexão 
metafísica. Antes de toda a história de um campo problemático tão vasto e fecundo como o da instauração da dualidade nos mais variados âmbitos - desde a sua tematização cosmogónica, mitológica, simbólica, política e até geo-mórfica no Egipto ${ }^{(24)}$, antes do seu nebuloso aparecimento numa esfera mais filosófica na Grécia Antiga ${ }^{(25)} \mathrm{com}$ as suas não inteiramente inovadoras cosmogonias órficas, passando pela sua problematização pelo romantismo alemão com Schelling, pelo seu surgimento fulgente na obra de Hegel, bem como toda a fenomenologia procedente -, Marija Gimbutas numa obra que nos parece escutar com a devida atenção a mais primorial linguagem do Ser que até hoje se nos ofereceu, em The Language of the Goddess perscrutou já as primevas expressões (calculadas entre 6500 a 3500 a. C.) do aparecimento documentado daquilo que efectivamente chega a denominar como uma "metafísica da abertura" inserida numa sociedade pré-androcrática $^{(26)}$. Com uma obra de investigação arqueológica e com um cariz eminentemente de averiguação filosófica, Gimbutas debruçada sobre as abundantes representações escultóricas e pictóricas do poder sexual masculino, muitas das vezes obsessivamente trabalhadas, ousa nesta proposta verdadeiramente inaugural e que daqui congratulamos, entrever o início desta problemática na representação permanente e quase obsessiva da fecunda cisão carnal observada desde logo nos grandes lábios do sexo feminino e posteriormente representados em brutais imagens escultóricas. Se com a introdução do pensar conceptual grego esta problemática ganha sem dúvida novo fôlego, para além do que primitiva e etimologicamente jaz na mentalidade da

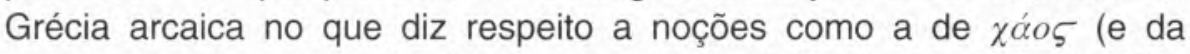
sua respectiva procedência da grega raiz $k a^{(27)}$, justamente familiar com ideias de "ruptura», "cisão", "fissura» e até "bocejo»(28) ${ }^{(28)}$ o que se nota com a construção teorética que subjaz, cremos, pelo menos de forma inconsciente, ao pensamento plotiniano não é senão uma forma deste modo próprio do pensar metafórico, desta vez trabalhado conceptualmente no interior do pensamento teológico da época: a dualidade metafísica é corolário da possibilidade da existência, mas este quadro não poderia ser efectivado sem uma resposta que procurasse diluir o pensamento filosófico no que foi postulado como seu fundamento último.

Vimos já como se entroncam e se impregnam os dois principais eixos da filosofia plotinana: a questão do fundamento em si e a temática do que dele procede, da forma como deriva e como preserva o 
que dele depende, é, cremos, a pedra de toque da obra de Plotino. Já vimos também como esta construção teórica é obra de um sentimento religioso manifesto por um pensar que procurava categorias metafísicas explicativas. Walter Burkert no seu já clássico Griechishe Religion in der Archaischen und Klassischen Epochen constata e documenta a ascensão da filosofia como tradição intelectual da humanidade com um novo ponto de partida: o Ser e o Divino. Com Plotino, embora já certamente distante no tempo da época de aurora filosófica que Burkert caracterizou, encontramos exactamente o reflexo do mesmo.

Inerente ao pensamento filosófico, o grande motivo da consciência religiosa está bem explícito na coluna vertebral da obra plotinana: já o relevamos no fundamento e no próprio corpo articulado da sua obra - mas em Plotino a questão de um «além ontológico" emanentista e até, de certa forma, panteísta, converge para a ideia de uma resolução da pluralidade numa efectividade que reconheça o infinito na finitude. A construção metafísica plotiniana é uma resposta construtiva à procura do fundamento ontológico dos entes. Toda a busca por um fundamento, diz-nos Hans Albert, pode cair em três géneros de fundamentalismos: 1 - o regresso infinito e recursivo onde se procura 0 fundamento do fundamento ad infinitum; 2 - a fixação em algo arbitrariamente escolhido como fundamento e que depois afinal se revela no interior da reflexão ser ainda fundamentado; 3 - o puro e simples investigar algo como fundamento e posteriormente construir toda uma teia de sentidos coadunados com esse princípio. Evidentemente de que pelo menos em Plotino estamos de forma nítida na última possibilidade desvelada por Hans Albert: o Uno emerge investido de um acrescento de sentido que não existia de maneira alguma em Platão ou Aristóteles. O Bem é o resultado e o princípio da estrutura fenoménica do mundo: o Bem no seu aparecer representa-se, ou seja aparece como um não-verdadeiro, uma finitude, um ente na pluralidade do mundo. Cada ente é uma imagem do Uno, do Bem: cada ser é uma representação do absoluto e da sua excessividade produtiva. A resposta radical de Plotino está, depois, em introduzir a ideia de um regresso dos entes ao seio de onde procederam: a divina dramaturgia, a divina tragédia estrutura-se justamente também neste duplo e sincrético eixo de um Deus do qual só na aparência da representação desabrocham os seres. Aparência e verdade absoluta convivem no paradoxo do indiferenciado primitivo da entidade sobre a qual Plotino investiu o sentido da metafísica sistemática que constrói: o existir dos entes visto de uma perspectiva como distância, pode de igual modo 
ser visto como um movimento de vir ao encontro consumado de si mesmo. A metafísica de Plotino é a história dramática de um movimento resoluto do vir à presença dos entes que aparecem e se preservam na diferença da vida violenta através de uma angústia pelo que Ihes é próprio - no plano da representação - e em paralelo da consumação essencial e arrebatada destes na união do que na verdade nunca deles se separou. No Uno, algo é diferenciado dele e por ele: é como se fosse por ele mesmo, por si próprio, algo para outro. Mas toda a questão subjaz nesta subtileza do pensamento plotiniano: o que é separado nesta distinção permanece, pelo diferenciar, precisamente referido àquilo que distingue. O Uno separa, representando em hipóstases algo de si: todavia, em simultâneo, acrescenta a si mesmo o separado. O Bem é um separar-se que na radicalidade absoluta da infinitude não o é: esta ambiguidade evidencia a essência do representar do Bem. O dramático, o elemento teatral e narrativo que perpassa transversalmente toda a metafísica de Plotino está desde logo na ambiguidade essencial do Uno e da distinção para a diferença dos entes do representar que por outro lado simultaneamente não é nenhuma distinção: do Uno depende a própria possibilidade desta duplicidade anfíbia da potência e da actualidade da emanação e reunião das figuras de si mesma. Tudo o que é ente existe: inteligível ou sensível - a sua existência é garantida por um fundamento numa instância que só pode ser entendida como negativa, como indiferenciada na medida em que é entendida a partir do que é negado e da sua perspectiva própria. A $\delta \dot{v} v \alpha \mu \varsigma$ a partir do ponto de vista desta

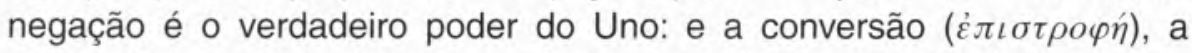

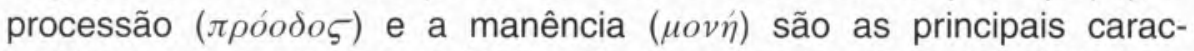
terísticas que animam toda a estrutura do pensamento plotiniano. O reconhecimento da verdade, a inversão e o regresso da perspectiva unilateral do ente ao Uno revela-se - como aliás atrás tivemos já oportunidade de focar no comentário da passagem ao texto de Plotino por nós trabalhado - um regresso do Uno a si mesmo, ao próprio Uno, que é o verdadeiro sujeito e protagonista desta epopeia da metafísica ocidental. A (trans-)visão unitiva de uma luz que desoculta o cintilar do infinito na finitude dos objectos comuns desvela-se, afinal, como um remover do que impedia o Bem de reconhecer o seu imo, a sua natureza íntima e última. Livre de essência, e apenas com 'uma certa intuição de si', a alma desvela-se como Bem último, sendo ela mesma coincidente com o centro de todos os centros, numa circularidade perfeita. 
Em última análise, o desejo do Bem revela-se ser transversal a todos entes: funcionar para o seu incremento, dirigido para si mesmo, numa circularidade divina e ambígua na duplicidade de contextos que pode ser perspectivada. Com Plotino estamos perante um universo inteligente, uma realidade que concorre na totalidade para o Bem - e daí que o imperativo ético da pedagogia seja o lugar por excelência da única liberdade possível: o da necessidade e da coincidente liberdade de conversão ( $\dot{\varepsilon} \pi \iota \sigma \rho \rho \varphi \eta ́)$ e da descoberta dos contextos interpretativos dos planos das realidades representadas no drama da separação e da reunião.

\section{Conclusão geral}

A metafísica de Plotino pode ser pensada em profundidade como o trabalho especulativo em torno da história religiosa e dramática do movimento resoluto do vir à presença dos entes, do seu aparecer para a vida e para o cuidado do que Ihes é próprio e do seu simultâneo regresso à sua origem. A macro-estrutura do pensamento plotiniano organiza-se justamente em torno de uma narrativa dramático-trágica onde uma entidade superior, por excesso criativo, cumpre o círculo de uma cíclica conversão e processão em direcção à sua origem. Por liberdade e por uma coincidente necessidade da sua vontade, a viagem deste Uno através de si mesmo, qual sujeito de todos os sujeitos, ilumina-se essencialmente como um poderoso jogo de tensões entre a pluralidade irresoluta e a unidade criativa ${ }^{(29)}$.

\section{Notas}

(1) Neste trabalho temos praticamente sempre em conta a tradução já clássica de ARMStrong, A. H., Plotinus, Text with English translation by A. H. Armstrong, 7 vols., Cambridge Mass., 1966-1988, I, p. 267.

(2) O Uno tem naturalmente este carácter auto-emanativo, mas, como de resto veremos já de seguida, nele nunca ocorre nenhuma diminuição de carácter ontológico. DODDS, no artigo "Tradition and Personal Achievement in the Philosophy of Plotinus", refere bem a propósito do que dizemos: "There exists a non-reciprovating relationship between the One and its effects [...]: the higher determines the lower without itself being determined or modified by its own causative activity." Cf. The Ancient Concept of Progress, Oxford, 1973, p. 131.

(3) Sobre o que aqui referimos, as palavras de A. H. ARMSTRONG, em Plotinus: A Volume of Selections (London, 1953, p. 33) são tão fundamentais que John Rist, em The Road to Reality (Cambridge, 1967, p. 67), as considera como "the best traditional account" do 
processo de emanação da alma a partir do Uno. Vale com certeza a pena citar pelo incrível poder de síntese: "Nous proceeds from the One and Soul from Nous without in any way affecting its source. There is no activity on the part of the One, still less any willing or planning or choice. There is simply a giving out which leaves the source unchanged and undiminished. But though this giving out is necessary, in the sense that it cannot be conceived as not happening otherwise, it is also entirely spontaneous: there is no room for any sort of binding or constraint, internal or external, in Plotinus's thought about the One".

(4) Cf. STANISLAS BRETON, Rien ou Quelque Chose. Roman de métaphysique, p. 13.

(5) N. B.: Vejam-se as palavras de NAGUIB BALADI em "Origine et Signification de l'Audace chez Plotin", na obra Le Néoplatonisme: "En tout cela, l'audace est essentiellement liée à la séparation et à l'altérité"; Cf. Le Néoplatonisme, Royaumant, 1971, p. 89. Sobre a problemática da origem desta questão a bibliografia é praticamente infinita uma vez que os especilistas se dividem entre a recondução desta problemática aos neo-pitagorismos de então ou, fundamentalmente, às correntes gnósticas que de igual modo pululavam no ambiente cultural da época de Plotino. A grande obra de referência sobre a cultura e os seus matizes continua a ser a de ARMSTRONG em The Cambridge History of Later Greek and Early Medieval Philosophy, Cambridge University Press, Cambridge, 1970.

(6) Cf. Ibidem, p. 89, "Entre l'Un et les autres hypostheses, en deçà de I'Un et aux différents niveaux de l'être, entre l'être divin et l'être sensible, il y a un rapport originel qui prime celui de la procession de l'émanation, d'une procession qui est émanation. Le surgissement de l'être, la multiplicité propre à l'être intelligible, la variété infinie et infiniment concrète de ses manifestations, la dualité irréductible de l'intelligence et de l'intelligible, l'apparition du sensible, l'union de l'âme au corps, le mal comme la mort, tout cela ne saurait être compris ni expliqué dans un système d'émanation pure, et en vertu de la simple position de l'Un, de la profusion et de la surabondance de sa puissance. Ce sont là certes des conséquences qui peuvent être rattachées directement à l'Un et à sa toutepuissance, mais qui présupposent, un peu partout des fissures ou des éclatements, tout au moins une altérité et des différences irréductibles. Si l'Un est principe premier et absolu, l'avènement de ces effets requiert comme un principe second qui fait que l'être surgit et que l'altérité prend droit à l'être. Ce principe de surgissement et finalement de séparation, est l'audace même.”

(7) Cf. "The Soul in Gnosticism and Plotinus", in Le Néoplatonisme, Royaumant, 1971, p. 52.

(8) Cf. P. A. MEIJER, Plotinus on the Good or the One, J. C. Gieben Publisher, Amsterdam, 1992, p. 105.

(9) Sobre esta questão do microcosmo/macrocosmo vide o tratamento que the é dado na capital obra de ARMSTRONG, The Architecture of the Intelligible Universe in the Philosophy of Plotinus, Cambridge University Press, 1940, p. 113. Pela importância de uma passagem vale a pena citar: "[...] the tradicional Greek idea of the close correspondence of the macrocosm and the microcosm is the essential foundation of his system. [...] He does hold that man's mind and soul are part of a universal mind and soul which produce and vitalize the universe and that the structure of the universal rulling principle can be deduced from the the study of the ruling principle in man".

(10) Interessa talvez reter a seguinte passagem de ARMSTRONG na sua monumental obra, The Cambridge History of Later Greek and Early Medieval Philosophy, onde a propósito da descrição da filosofia plotiniana, como um misticismo de carácter teísta, se refere: "[...] the soul seeks to attain a union with the Absolute of which the best earthly analogy is the union of lovers, not a mysticism in which the soul seeks to realize itself as Absolute [...]". Cf. A. H. ARMSTRONG, The Cambridge History of Later Greek and Early Medieval Philosophy, Cambridge, 1970, p. 263. 
(11) Cf. Ibidem, En., VI, 7, 36. É também a opinião expressa por PAULO BORGES em "O Desejo e a Experiência do Uno em Plotino", Philosophica - Aristóteles em Contexto -, Edições Colibri/Departamento de Filosofia da Faculdade de Letras da Universidade de Lisboa, 2005, p. 201.

(12) Cf. A introdução à tradução da obra completa de PLOTINO que neste trabalho utilizamos: I, p. 50.

(13) Cf. H., J., KRÄMER, Der Ursprung der Geistmetaphysik, Amsterdam, 1964, p. 342.

(14) Cf. MEIJER, P. A., Plotinus on The Good or the One - Enneads VI, 9 - An Analytical Commentary, Amsterdam, 1992, pp. 243-245.

(15) O termo é cunhado por MEIJER, P. A., Plotinus on The Good or the One - Enneads VI, 9 - An Analytical Commentary, Amsterdam, 1992, p. 231.

(16) Cf. J. M. RIST, 'Theos and the One in some Texts in Plotinus', Classical Quarterly, 12, 1962, pp.99-107. N. B.: Rist, neste artigo que se tornou ponto de encontro obrigatório dos

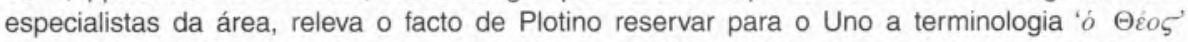

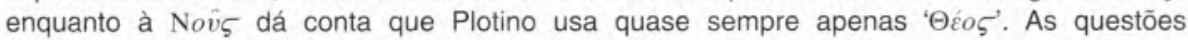
que convergem para este uso da terminologia teológica procedem de forma primordial evidentemente de Platão e de Aristóteles. Sendo um sintoma da posição plotiniana face aos movimentos religiosos da sua época, não deixa de ser interessante e de ter o seu grau de conspicuidade o paralelismo a explorar com o texto de João 1 , 1 na Bíblia em

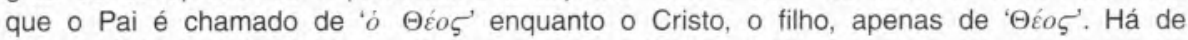
resto indícios em III, 2, 8 das Enéadas de que Plotino tinha conhecimento do movimento primitivo cristão. Esta problemática extravasaria em larga escala o que neste trabalho se procura essencialmente focar; fica no entanto o repto de se pensar o referido.

(17) Cf. PAULO BORGES em "O Desejo e a Experiência do Uno em Plotino", Philosophica - Aristóteles em Contexto -, Ediçōes Colibri/Departamento de Filosofia da Faculdade de Letras da Universidade de Lisboa, 2005, p. 212.

(18) N.B.: O uso dos termos relacionados com o tema do "drama" e da "mitologia" nesta reflexão está longe de ter um teor técnico. Por "drama" aproximamo-nos de uma ideia lata e generalista da narrativa literária (representada ou não) onde o atrito ou o conflito são caracteristicamente o móbil da progressão última e do próprio movimento de toda a narrativa.

(19) Cf. RUDOLF OTTO, O Sagrado, trad. de João Gama, edições 70, 1992, p.33.

(20) Neste capítulo muito haveria certamente a explorar nos campos filosóficos mais inesperados. Em boa verdade, somos da opinião, cada vez mais radical, de que a filosofia europeia, tal como se constituiu e constitui até à data, obedece exactamente à mesma estrutura que parece constituir de fundo a filosofia de Plotino. No caso da fenomenologia existencial de Sartre, a título de exemplo, estamos perante uma composição metafísica claramente de inspiração semelhante: ali concatenam-se várias modalidades da presença de si a si, ou de mim a outrem. O outro nunca é dado numa mera relação de adição e a sua primeva modalidade não é a da objectividade nua: diferentemente, o outro aparece como pura desintegração do mundo que até então era uno com a consciência absoluta. Toda a relação mundana desloca-se para ele, é fuga permanente das coisas em direcção a um sujeito-olhar que enquanto escapa desdobra à sua volta as suas próprias distâncias e simultaneamente constitui-o como objectividade numa mundaneidade temporalizada, num mundo já descentrado do não ter limites na plenitude do en-soi. Num tipo de discurso claramente de cariz existencial, temos: a hemorragia interna do mundo é a queda do eu ser o meu próprio nada para um ser que é o que é e reflexamente não é o que é. Aqui introduz-se o que anteriormente referimos, e daí a nossa insistência; é que o ser-para-outrem parece justamente ser o prolongamento da pura cissiparidade reflexiva: o perene 
escapar-se a si própria da reflexividade no circuito do reflectir e do reflectido é a matriz formal pela qual tenho consciência de mim como ego que apreendo como não sendo por princípio para mim, mas para o outro. Sou o meu ego para outro, isto é, não o sou numa qualquer forma do simples "ter de ser"; não: sou-o enquanto me foge para o outro, a minha transcendência-transcendida, num mundo que através da sua liberdade me alienou, cristalizando-me nas minhas possibilidades mortas, na minha ultrapassagem de ter sido visto. Torno-me possibilidade morta pela mera probabilidade de ser ou meramente poder ser ultrapassado: as minhas possibilidades tornam-se presentes a mim mesmo enquanto sou o ser que não sou e o ser que sou, em suma, enquanto sou o ser-alguém-aí lançado para o mundo por um olhar que me instala na dolorosa e fugidia ignorância da opacidade mundana. "Ma chute originelle c'est l'existence de l'autre" (Cf. J.-P. SARTRE, L'être et le néant - Essai d'ontologie phénoménologique, Mesnil-sur-l'Estrée, Gallimard, 2003, p.302.), por outras palavras: o outro é a morte subtil das minhas possibilidades, o être-au-mileu-du-monde-pour-autrui espacializa-me e temporaliza-me na co-presença da simultaneidade enquanto me constituo objecto de apreciação: o aparecimento do outro coloca-me numa "situação" que por princípio me escapa e da qual não sou senhor.

As problemáticas de Sarte e as soluções que encontra são, cremos, surpreendentemente semelhantes aos problemas postos por Plotino. Na linha do idealismo clássico alemão, a mesma estrutura metafísica parece ser o ânimo de fundo do seu sistema: quase entrando num diálogo aberto, quer com uma analogia exegética da adamantina queda, quer no problema da "rebeldia" dos entes que temos vindo a focar no âmbito plotiniano, Hegel justapõe os dois hipotéticos planos ontológicos distinguidos por SARTRE: “O mal está localizado no acto da cognição, na consciência. [...] Consciência significa em geral julgar [Ur-teil; divisão primitiva] e dividir, é uma auto-distinção [inaugural] que ocorre na interioridade de cada um. [...] A clivagem [Ent-zwei-ung; divisão em dois] é o que é o mal; é a contradição" (Cf. HEGEL, "Lectures of 1827 - The Consumate Religion", in Lectures of the Philosophy of Religion, III, ed. by Peter C. Hodgson, transl. by R. F. Brown, P. C. Hodgson, and J. M. Stewart, assist. by J. P. Fitzer and H. S. Harris, London, University of California Press, 225, p. 301.). A interpretação fenomenológica da fissura, da negação que perfaz a consciência é explicitamente semelhante ao que de um ponto de vista geral se encontra no filósofo egípcio. Esta ideia da cisão maldita perpassa macroscópica e microscopicamente toda uma arcaica "metafísico-noo-onto-teologia" da separação que assenta sempre sobre a verfallen, a queda de uma entidade superior central, ou seja, do Uno, ou da consciência englobante, ou do sujeito-todos-os-sujeitos. A mitificação do olhar e do ver metafórico está também trabalhada nestes autores: a ek-stase que propulsiona todo o desenrolar do espírito, toda a série solidificada de figuras da consciência é, para Hegel, possibilitada primitivamente por uma auto-contemplação objectivante do espírito que de forma em forma se instala numa ilusória independência finita. A famosa dialéctica do filósofo alemão aduz então que, de finitude em finitude, "o espírito se contempla a si próprio, e dá lugar à emergência da sua própria ruptura" (Cf Ibid, III, 141, p. 209.). Na separação da ruptura, o sujeito subjectivo define-se a si mesmo, auto-determina-se no seu limite, conceptualiza-se como o extremo do abstracto ser para si, como abstracta liberdade. 0 espírito a si mesmo se olha - quer isto dizer que a si mesmo, ou de si mesmo (se) compreende outro, se retira para o aparecer do outro: este movimento de abstracção do espirito, este sério auto-trespassamento corresponde à sua essencial espontaneidade: tudo se joga na seriedade deste olhar que é de tal forma investimento de sentido que o sujeito sujeitado à subjectividade receosa, orgulhosa ou envergonhada - em suma, absurda -, ao ser radicalmente atirado para baixo no infinito sofrimento e angústia, a si mesmo se arranca para a nunca realizada reunificação completa na multiplicidade escandalosa dos vivos, imbuídos na teia fenomenal do essencial aparecer do espírito. No todo do movimento compreendido como repouso absoluto, o que se dá aí no ser particular é o duplo movimento do em-si na direcção da verdade do em-si e do para-si das consciências: na 
Phänomenologie, a dialéctica espiralóide do espírito tem um correlativo exacto no plano das consciências que face a face se acercam. A chave da compreensão do que anima o edifício filosófico de Hegel, é que se exige a realização cumprida da subjectividade. $O$ desenrolar da essência em manifestação num crescendo nocturno do desespero corresponde ao seu caminho pela errância do absoluto dilacerado pelo trânsito em devir entre o ser e o nada das formas.

No campo de uma certa filosofia heideggareana, a insistência muda um pouco de foco; aqui o principal objecto de estudo é nitidamente feito do ponto de vista do sujeito e da exegese do que de puramente metafísico se desenrola na vivência do humano. Não deixa no entanto de estar bem patente, na opus magnum do autor - Sein und Zeit - a ideia de que o ente existe rasgado para a solidão abstracta do absoluto mundano sem mediações, do absoluto apenas re(com)duzido à diabólica certeza sensível, ocupando-se estritamente dos seus limites, por mor de si mesmo e tornando-se um sujeito que caminha para o seu incremento, empenhado e comprometido com o mundo coisistico do quotidiano.

Em última análise, em Kant, observamos toda uma linha de pensamento muito semelhante à que temos vindo a observar. Com consciência de que o contexto não é o mesmo, não podemos deixar de aproximar a tragicidade com que Kant descreve uma razão crítica que se abeira do abismo do pensar e a tragédia em que um Espírito hegeleano se desenrola. Em planos diferentes a "necessidade incondicionada" é o abismo da razão humana tal como o é para o espírito: mas ambos se perturbam na mais extrema das questões - no fundante "de onde sou então?" -, e ambos, neste interrogar abissal, se fundam no incondicionado. A par desta passagem, a lição de Kant na Crítica da Razão Prática (trad. Artur Morão, Lisboa, Edições 70, 2001, A 258-259, p. 163) parece-nos claramente nodular. A coluna vertebral que vislumbramos na razão kanteana é justamente uma carência fundamental que internamente a constitui e pela qual cosmogonicamente e segundo as leis próprias de um sujeito transcendental recebe a realidade e funda objectivamente postulados que em suma reconstituem a sua identidade perdida. O que em Hegel foi justamente mais além com o Espírito, leva também em si a memória kanteana de uma amorosa carência abissal fundante. É precisamente este cosmogónico Eros que anima interiormente o sistema hegeleano até à ciência sujeito do sistema. Muito de nossa parte haveria neste passo a observar minuciosamente. $\mathrm{Na}$ verdade este processo de investimento total numa só unidade que incondicionada na carência e no terror surge e assim garante a segurança de um Kósmos - como, por exemplo, a razão kanteana -, encontra-mo-lo desde logo expresso nas mais arcaicas tradições gregas, nomeadamente em todo o axial eixo que orientava a críptica história do que se enreda em torno do olímpico divino. Desde os consecutivos destronares dos primordiais pares divinos, como Urano e Gaia, Cronos e Reia, onde o máximo representante do poder divino em constante sobressalto acaba sempre por ser destronado, parece-nos no entanto de relevar o facto do último grande divino soberano da tradição religiosa grega ser um deus arcaicamente associado à demarcação de fronteiras e de propriedades (vide étimo de Zeus). Dentro do imaginário mítico-religioso da mentalidade grega, de igual modo nos parece de relevar a genuína hegemonia despótica que este deus, uma vez tendo assumido o poder, exerceu junto de todo o élan titânico (cujo nome grego não por acaso nos remete para o vocábulo titainein sugerindo a ideia de um "ultrapassar-se", de um "ultrapassar o que é devido à ordem"). O que mais nos importa salientar prende-se com o simples facto de em Zeus - tal como de resto um Erich von Neumann ou um Kerényi em larga escala o entreviram -, na sua desmesurada pretensão hegemónica de dominar toda e qualquer potência ontológica procedente ou mais próxima do caos primordial, assegurando assim uma ordem aparentemente estável e definitiva do mundo, se poder ver com suficiente claridade a mesma vontade que caracteriza uma quiçá razão arrogante de Kant (estará por escrever, segundo os arcaicos modos do pensar, uma mitíco-poética da razão kanteana?). Pode o leitor achar despropositada esta nossa leitura, no entanto tal interpretação veiculamo-la directamente da leitura do 
platónico Crítias e, fundamentalmente, de um Timeu, onde se relata o cruento conflito entre Atlântida e Atenas, representações por excelência do antagonismo entre as titânicas potências marítimo-ctónicas e o ateniense regime político que orgulhosamente se assegura conforme a justiça. Em Proclo, nomeadamente na sua interpretação deste autêntico panegírico a Atenas, de igual modo é de evidenciar toda a interpretação deste autor ao transpor toda esta olímpica visão do que pelo menos à superfície aparece num plano mítico-religioso para o metafísico. Para tudo o que aqui foi dito e para além dos platónicos textos a que aludimos - já que julgamos ser mais ou menos do conhecimento do vulgo tenham-se em conta as seguintes obras: PIERRE VIDAL-NAQUET, "Athènes et l'Atlantide. Structure et signification d'un mythe platonicien", in id., e JEAN-PIERRE VERNANT, La Grèce Ancienne. I - Du mythe à la raison, 1997; C. KERÉNYI. The Gods of the Greeks, USA, Thames\&Hudson, 2000; PROCLO, Commentaire sur le Timée, I, trad. e notas de J. Festugière, Paris, J. Vrin, 1966.

(21) Cf. RUDOLF OTTO, O Sagrado, trad. de João Gama, edições 70, 1992, p. 33.

(22) N. B.: Evidentemente temos em conta a homérica Odisseia (para uma curiosa relação entre o sol e o tema do regresso, vide Od. XIII, vv. 28-30) e toda uma antiga tradição que insiste particularmente na temática do "regresso". O tema de um vóoto५ é um aspecto fundamental da obra plotiniana; note-se bem que, a título de exemplo, a obra monumental The Cambridge History of Later Greek \& Early Medieval Philosophy dedica dois capítulos justamente ao tema, intitulando-os, aliás, do seguinte modo: «From Intellect to matter: the return to the One" e "The return: the religion of Plotinus". (Cf. The Cambridge History of Later Greek \& Early Medieval Philosophy, ed. A. H. Armstrong, Cambridge University Press, 1970 , pp. 250-264.) Como prometemos na introdução, não se pretende nesta reflexão retraçar filogeneticamente o que subjaz ao pensamento plotiniano. Mas a necessidade do escândalo - como por exemplo surge depois em Mateus 18, 7 - na direcção da alienação progressiva do absoluto, corresponde a nosso ver, seguramente à sistemática reformulação do que de uma maneira ou de outra estruturalmente se entrevê nas arcaicas figuras com uma função mítico-ritual de um divino que "morre" inserido nos mais variados teo-dramatismos culturais. Neste contexto, relembramos a leitura de Mircea Eliade: "a vida religiosa, tal como as criações a que deu origem, estão dominadas por aquilo a que poderiamos chamar "a tendência para o arquétipo" [...] a sua expressão tende a regressar continuamente ao arquétipo.[...]"; Cfr. MIRCEA ELIADE, Tratado de História das Religiōes, pref. de Georges Dumézil, trad. de Fernando Tomaz e Natália Nunes, Lisboa, Edições Asa, 1997, pp. 93; 481-504. Conforme esta leitura, estamos, cremos, com Plotino na presença de uma das maiores construções teóricas sistemáticas desta "vida religiosa". A ideia de um retorno ao arquétipo no texto plotiniano parece-nos basilar.

(23) A terminologia do "esvaziamento" é utilizada por Plotino. Apesar de no texto plotiniano não estarmos de maneira alguma no âmbito de uma consciência cristã e evidentemente numa esfera de trabalho especulativo de carácter cristão (Cf. JOHN RIST, "Plotinus and Christian Philosophy", in The Cambridge Companion to Plotinus, 1966, pp. 386-413.), cremos que se torna quase evidente e impossivel não relacionar esta temática plotinana com as paradigmáticas palavras de Paulo na Epistola aos Filipenses, quando se refere a "Cristo Jesus" e à famosa lógica da kénosis. O que nos importa reter aqui é a dupla e paradoxal lógica da kénosis: ao escândalo do auto-esvaziamento ou da auto-evacuação, ao sacrifício total e doação plena na odisseica excessividade incontinente do "amor» e da "compaixão" (Filipenses 1, 21-26) corresponde talvez a anulação do sujeito na desmesura do vazio, que agora sempiternamente se "outra entre-sendo" na divina loucura de tudo poder ser de todas e quaisquer maneiras. O que queremos realçar nesta anotação é o lugar comum na consciência religiosa que opera igualmente no pensamento metafísico de Plotino. Veja-se que também no âmago do cristianismo, a misteriosa lógica da kénosis noctívaga experiência da humilhação fundamentalmente presente na paulina expressão 
que citámos -, a total ruptura na noite do Espírito entronca por sua vez também numa estranha dialéctica da perdição/salvação que tantas vezes a Bíblia nos apresenta - em Lucas 9, 24;17, 33; Marcos 8, 35; Mateus 10, 39; 16, 25; João 12; 25.

(24) Não é certamente aqui o local para uma exposição sobre o que ultimamente estudámos e pensamos sobre toda esta temática na história do Egipto Antigo. Parece-nos no entanto grave a total obnubilação e olvido em torno de algumas experiências ontológicas que nos parecem abrir a consciência da Grécia Antiga - nomeadamente dos pré-Socráticos - e evidentemente, agora no campo problemático deste trabalho, no judeo-cristianismo e especificamente no gnosticismo. Não resistimos a realçar a experiência ontológica egípcia numa ainda inexplorada proximidade da dupla raiz do verbo "ser". Seja como 4 (iw) - onde se pressente a proximidade etimológica do verbo "vir", s\$ (iw) -, seja na forma de $s=(w n n)$ - a partir da qual se pressente uma proximidade etimológica relativa ao adjectivo $-\sqcup \smile(w n)$, "aberto/a" - tanto uma preconização da grega parousía, como da abertura fundamental do ser, parecem-nos ser determinantes no modo como a Grécia arcaica intuirá alguns dos seus conceitos mais basilares. Vide: SIR ALAN GARDINER, Egyptian Grammar, Oxford, Griffith Institute-Asholean Museum, 2001, §107 e §468. Para as etimologias que avançamos, um bom dicionário pode ser usado: RAYMOND O FAULKNER, A Concise Dictionary of Middle Egyptian, Oxford, Griffith Institute, 2002, os respectivos verbetes na p. $11 ; 60$.

(25) Um estudo com o seu interesse e em parte focando esta temática é o de Paulo $A$. E. Borges em PAULO ALEXANDRE ESTEVES BORGES, "Imaginário mitico-metafísico do Oceano e do extremo-ocidente Atlântico", O Mar, Lisboa, 1998; bem como do mesmo autor Princípio e Manifestação no Pensamento Contemporâneo Português, dissertação de doutoramento em Filosofia apresentado à Faculdade de Letras da Universidade de Lisboa, (policopiado), Lisboa, 1998, pp. XXI-XXVI.

(26) Não nos podemos estender sobre o assunto tanto como deveríamos. No entanto, há outros autores que podem ser lidos com algum proveito, relevando não só outros aspectos como fazendo leituras bem diferentes da que aqui apresentamos. Fica o repto para ser devidamente pensado e encaixado na nossa perspectiva: ERIC NEWMAN, The Great Mother, trad. do alemão por Ralph Manheim, USA, Princeton University Press, 1983; C. G. JUNG, Aspects of the Feminine, trad. de R. F. C. Hull, USA, Princeton University Press, 1991; M. STONE, When God was a Woman, New York/London, Harvest/Harcourt Press, 1978; ANDRÉ LEROI-GOURHAN, Les Religions de la préhistorie, Presses Universitaires de France, 1964; PIERRE SOLIÉ, La femme essentielle - Mythanalyse de la Grand-Mère, Paris, Seghers, 1980. Seguindo nós uma das preciosas lições que coligimos de ANDRÉ LEROI-GOURHAN em Les Religions de la préhistoire, no âmbito próprio deste primeiro murmurar do homem e seu auroral nascimento para a verdade, tal como toda uma série de tradições religiosas e culturais postulam o amanhecer do mundo através de um romper causador da primordial cisão, não deve com certeza ser por mero acaso da fortuna que uma das primeiras e mais obsessivas representações do homem pré-histórico passa precisamente pela exibição do feminino, de signos explicitamente vulvares aliados - por exemplo em Pech-Merle (sobre estas grutas particulares vide a curiosa obra de Göran Burenhult The Illustrated History of Humankind ) - à representação de feridas. Muito haveria a pensar no que diz respeito a esta não acidental associação entre abertura, cisão vulvar e ferida: as ressonâncias metafísicas profundas que tem no pensamento ocidental mereciam um estudo por si próprio. Não resistimos no entanto a sugerir que no campo etnográfico podem ser lidas interessantes informações no estudo de ROGER CAILLOIS, O Homem e o Sagrado, trad. Geminiano Cascais Franco, Lisboa, Edições 70, 1988, pp. 137-150. Ainda na esfera desta associação entre a cisão e o feminino, cremos ser de capital importância o jogo simbólico que a mero título de exemplo é feito no Antigo Testamento, quer nas passagens do Génesis, onde se alude a um acto de separação por parte de 
Deus, quer aquando da já muito glosada separação das águas por Moisés e no respectivo fechar do Apocalipse 21, 1 et passim onde se apela a vinda de um "céu novo" e uma "nova terra" onde o caótico mar não mais teria existência. As associações entre o feminino e o elemento aquático levar-nos-iam demasiado longe (o tratamento dado por MIRCEA ELIADE no Tratado da História das Religiōes seria imprescindivel para tal debruçar no assunto). No plano de uma filosofia da biologia e, portanto, surpreendentemente no centro de uma filosofia contemporânea que se exerce fundamentalmente no campo da metafísica, o trabalho de HANS JONAS no seu Das Prinzip Verantwortung, tem de facto as suas raízes profundas numa fundamentação ontológica e ôntica da problemática da cisão, do rasgo da liberdade dormente na naturalidade para a existência passional dos sujeitos e da sua instalação na perspectiva do vivo. Para constatar o que referimos basta ler: HANS JONAS, "To Move and to Feel: On the Animal Soul", in The Phenomenon of Life, with a foreword by Lawrence Vogel, Illinois, Northwestern University Press, 2001; bem como, HANS JONAS, "Evolution and Freedom", in Mortality and Morality - A search for the Good after Auschwitz, with a foreword by Lawrence Vogel, Illinois, Northwestern University Press, 1999. Para o tratamento da questão da biologia no texto plotiniano vide: P.-M. SCHUHL, «Plotin et la biologie», RPhilos, 95, 1970, p. 77-78.

(27) Cf. G. S. KIRK, J. E. RAVEN, e M. SCHOFIELD, Os Filósofos Pré-Socráticos, trad. de Carlos Alberto Louro Fonseca, 4. ${ }^{a}$ ed., Lisboa, Fundação Calouste Gulbenkian, 1994, p. 32.

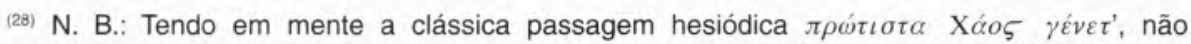
resistimos a relembrar a seguinte passagem: "Our ancient language has a Word for the void, 'Chaos', which simply means that it 'yawns'. Originally there was no word meaning turmoil or confusion: 'Chaos' acquired this second meaning only later, after the introduction of the doctrine of the Four Elements"; Cf. C. KERÉNYI, The Gods of the Greeks, USA, Thames\&Hudson, 2000, p. 17.

(29) Quero aqui expressar a minha profunda gratidão ao Professor Dr. Nuno Simões Rodrigues que me convidou a participar neste número da revista de História Antiga, Cadmo. Não posso deixar de relevar que a presente reflexão surgiu na esteira dos assuntos por ele abordados ao longo de um Seminário de trabalho. Os lapsos eventualmente presentes neste trabalho são da minha inteira responsabilidade. 